\title{
Ages of calderas, large explosive craters and active volcanoes in the Kuril-Kamchatka region, Russia
}

Received: July 23, 1993 / Accepted: April 28, 1995

\begin{abstract}
The ages of most of calderas, large explosive craters and active volcanoes in the Kuril-Kamchatka region have been determined by extensive geological, geomorphological, tephrochronological and isotopic geochronological studies, including more than $600{ }^{14} \mathrm{C}$ dates. Eight 'Krakatoa-type' and three 'Hawaiian-type' calderas and no less than three large explosive craters formed here during the Holocene. Most of the Late Pleistocene Krakatoa-type calderas were established around $30000-40000$ years ago. The active volcanoes are geologically very young, with maximum ages of about 40000-50000 years. The overwhelming majority of recently active volcanic cones originated at the very end of the Late Pleistocene or in the Holocene. These studies show that all Holocene stratovolcanoes in Kamchatka were emplaced in the Holocene only in the Eastern volcanic belt. Periods of synchronous, intensified Holocene volcanic activity occurred within the time intervals of $7500-7800$ and $1300-1800{ }^{14} \mathrm{C}$ years BP.
\end{abstract}

Key words Caldera ages - Explosive crater ages · Active volcanoes · Kuril-Kamchatka · Russia

\section{Introduction}

More than 60 volcanoes within the Kuril-Kamchatka island arc have been recently active (Vlodavets 1957). In Kamchatka, most active volcanoes occur in the Eastern volcanic belt, which extends southward from Shiveluch volcano $\left(56^{\circ} 47^{\prime} \mathrm{N}\right)$ in the north along east and south Kamchatka to the southern termination of the

Editorial responsibility: H.-U. Schmincke

O. A. Braitseva (两) · I. V. Melekestsev • V. V. Ponomareva Institute of Volcanic Geology and Geochemistry,

Petropavlovsk-Kamchatsky, 683006 Russia

L. D. Sulerzhitsky

Institute of Geology, Moscow, 109017 Russia peninsula $\left(51^{\circ} \mathrm{N}\right)$. A few volcanoes are located to the west of the belt (Fig. 1).

For more than 20 years our investigations within the Kuril-Kamchatka region have focused on documenting and dating the most significant volcanic events that occurred during the last $30000-40000$ years. The first studies were in the 1960s and 1970s, when complex geological-geomorphological techniques of dating volcanoes were developed (Melekestsev et al. 1970). Ages were determined from the following data: (1) specific morphological features and the degree of edifice preservation, which, among other things, is a function of time; (2) concordance with the topography and deposits, the age of which are known (mainly from the glacial formations of different ages); (3) lenses and bands of terrigenous deposits in volcanic rocks dated by spore pollen and diatomic methods; and (4) the position of intercalated tephra in the dated continental deposits and sea bottom sediments of adjacent marine areas. These techniques allowed the recognition of several groups of extinct and active volcanoes of different ages in Kamchatka (Table 1; Melekestsev et al. 1971). Most of the active volcanoes in the Kuril-Kamchatka region are geologically very young, having formed in the Late Pleistocene-Holocene (Melekestsev 1973). By 'active volcano' here, we mean its recently active cone, but not the whole volcanic center, the formation of which could have covered a much longer period of time. Volcanoes of groups I and II in Table 1 are inactive.

Essential progress in the study of the ages of volcanic landforms in Kamchatka has been made during the last 20 years due to detailed tephrochronological investigations and much radiocarbon dating. This paper presents a detailed account of the ages of most calderas, large explosive craters and recently active volcanoes in the Kuril-Kamchatka region based on geological, geomorphological and tephrochronological studies, and more than $600{ }^{14} \mathrm{C}$ dates. 
Fig. 1 A Map showing active and potentially active volcanoes which originated in the Late Pleistocene and Late Pleistocene calderas. B Map showing active volcanoes, calderas and craters of subcaldera eruptions which formed in the Holocene or at the very end of Late Pleistocene. 1, Multi-eruptive volcanoes (dominantly stratovolcanoes); 2, Krakatoa-type calderas; 3-4, Hawaiian-type calderas; and $\mathbf{5}$, craters of subcaldera eruptions. Volcanoes, calderas and craters are not to scale
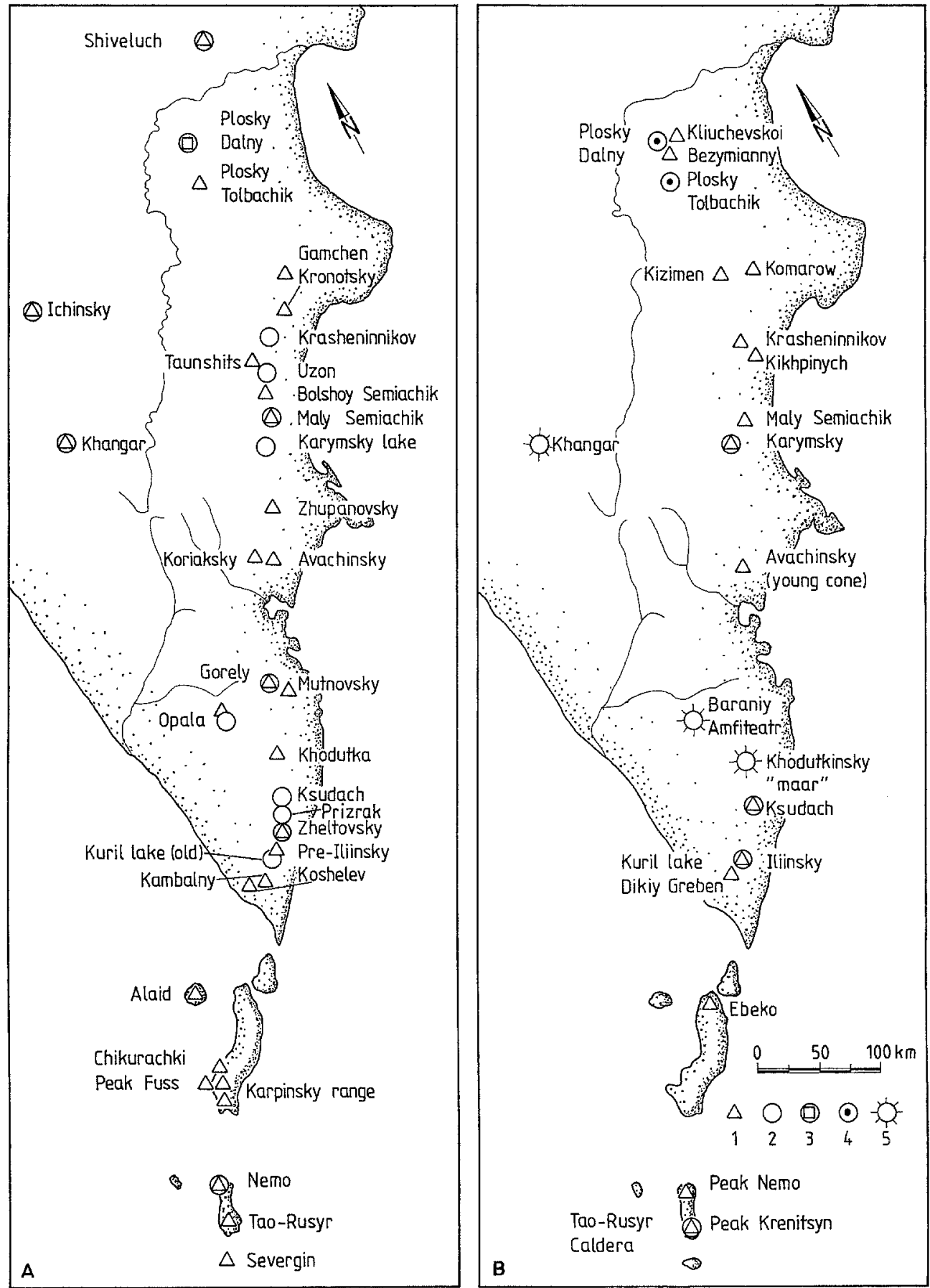

\section{Study methods}

Dating of Holocene volcanic landforms

\section{Tephrochronology}

The tephrochronological studies focus on the soil-pyroclastic sequence, which consists of tephras from different volcanoes separated by soils, eolian sandy loams or peats, and represents a geological chronicle of the explosive volcanic eruptions. The Holocene soil-pyroclastic sequence is a few tens of centimeters thick in the areas distant from the active volcanoes and increases up to several meters at their foot (Fig. 2). Firstly, we studied the soil-pyroclastic sequence near individual volcanoes to reconstruct their eruptive history. We then made correlations along long traverses in which detailed studies of soil-pyroclastic sections were made every $15 \mathrm{~km}$. The main traverse was along the Eastern volcanic belt of Kamchatka from Shiveluch volcano in the north to Kuril Lake in the south; many smaller cross-profiles were also added. As a result of these studies, ashes from most of the larger eruptions, which cover vast areas, were traced to their volcano source. The correlations were checked and added to by studies of the bulk composition of ashes and by ${ }^{14} \mathrm{C}$ dating. 
Table 1 Age groups of Quaternary stratovolcanoes of Kamchatka

\begin{tabular}{|c|c|c|c|}
\hline When the volvanoes formed & Volcanic edifice preservation & Correlation with glacial forms & Example volcanoes \\
\hline IV Holocene & $\begin{array}{l}\text { Well preserved edifices and } \\
\text { no traces of erosion are pres- } \\
\text { ent }\end{array}$ & $\begin{array}{l}\text { No traces of Late Pleistocene } \\
\text { glaciation. Recent glaciers oc- } \\
\text { cur occasionally }\end{array}$ & $\begin{array}{l}\text { Kliuchevskoi, Bezymianny, } \\
\text { Krasheninnikov, Karymsky, } \\
\text { Maly Semiachik }\end{array}$ \\
\hline $\begin{array}{l}\text { III Second half of Late Pleis- } \\
\text { tocene with continuing Holo- } \\
\text { cene activity }\end{array}$ & $\begin{array}{l}\text { Initial view of volcanic edifice } \\
\text { is preserved. Cones begin to } \\
\text { be dissected by deep gullies }\end{array}$ & $\begin{array}{l}\text { No sculptural glacial forms. } \\
\text { Large fields of moraine de- } \\
\text { posits are located at the feet } \\
\text { of volcanoes }\end{array}$ & $\begin{array}{l}\text { Ostry Tolbachik, Opala, } \\
\text { Kronotsky, Taunshits, Kho- } \\
\text { dutkinsky }\end{array}$ \\
\hline $\begin{array}{l}\text { II Late Pleistocene before the } \\
\text { onset of stage II of Late } \\
\text { Pleistocene glaciation }\end{array}$ & $\begin{array}{l}\text { Some eroson of volcanic edif- } \\
\text { ices. Large areas of the origi- } \\
\text { nal slopes are preserved }\end{array}$ & $\begin{array}{l}\text { Small and scarce sculptural } \\
\text { forms (cirques, troughs) of } \\
\text { stage II of Late Pleistocene } \\
\text { glaciation are present. Mo- } \\
\text { raines are located at the feet } \\
\text { of volcanoes }\end{array}$ & $\begin{array}{l}\text { Volcanoes of the Bolshoy } \\
\text { Semiachik group, Vershinsky, } \\
\text { Anaun }\end{array}$ \\
\hline $\begin{array}{l}\text { I Mid- and early Late Pleisto- } \\
\text { cene }\end{array}$ & $\begin{array}{l}\text { Strongly and moderately de- } \\
\text { stroyed edifices with frag- } \\
\text { ments of the original slopes }\end{array}$ & $\begin{array}{l}\text { Well expressed sculptural gla- } \\
\text { cial forms. Moraines of two } \\
\text { stages of Late Pleistocene } \\
\text { glaciation are located at the } \\
\text { feet of volcanoes }\end{array}$ & $\begin{array}{l}\text { Gorny Zub, Unana, Zhupa- } \\
\text { novskie Vostriaki, Aag, Arik }\end{array}$ \\
\hline
\end{tabular}

These tephrochronological studies resulted in a stratigraphic scale of tephra marker beds for the Holocene in Kamchatka (Table 2; Braitseva et al. 1992b; 1993). We have determined the areas of distribution for all marker ashes, as well as their characteristic features needed for correlation, including the stratigraphic positions of ashes, regularities in changes of particle diameter and thickness with increasing distance from the source, ages and bulk composition. The distinctive features of bulk composition of any ash are as follows: the presence or absence of mineral indicators such as biotite and hornblende and $\mathrm{K}_{2} \mathrm{O}$ concentration. These data allow the identification of marker ashes in soil-pyroclastic sequences in any region of Kamchatka. The ash horizons may be used as time markers for the determination of the age of deposits and landforms.

\section{Radiocarbon dating}

Our technique for ${ }^{14} \mathrm{C}$ dating of Kuril-Kamchatka volcanic deposits is summarized in Braitseva et al. (1992a; 1993). Along with traditional dating on charcoal and wood, we also used buried soils and peat for dating. In soil-pyroclastic deposits these soils are commonly represented by thin $((1-5 \mathrm{~cm})$ humic horizons. This organic matter is good for dating as it is well preserved by the pyroclastic deposits and typically represents only a short span of time. Provided a sufficient amount of organic material is available, it is possible to date several successive alkaline extractions from the same soil or peat sample. We believe that the results of the first and last extractions are close to the termination and onset of soil or peat layer formation. A date obtained without subdivision into extractions shows the mean age of the buried soil (for example, see section 6 in Fig. 3A). It is evident that the youngest dates of alkaline extracts are close in age to the overlying pyroclastic deposits.

Care must be taken with the soils or peat that overlie the pyroclastic deposits because the formation of the latter may sometimes be delayed depending on the growth rates of vegetation on fresh pyroclastic material. Nevertheless, the oldest dates of alkaline extracts from the soil overlying fine ash often show good concordance with the youngest dates from the soil underlying the same pyroclastic deposits (Fig. 3) and can be also used for timing the eruption.

The dates derived from charcoal and wood from the pyroclastic deposits are usually in good concordance with those obtained on peat and buried soils at the same stratigraphic level (Braitseva et al. 1992a; 1993). Some difficulties arise only in dating charcoals in pyroclastic flow and surge deposits as such charcoals and sometimes prove to be older the underlying soils (Figs 3C and 4; Sulerzhitsky 1970; Rubin et al. 1987; Braitseva et al. 1992a; 1993).

Tephrostratigraphic correlation of tephra marker beds allows results to be checked by comparing dates for the same stratigraphic intervals in soil-pyroclastic sections separated by tens to hundreds of kilometers (Fig. 3).

\section{Dating of Late Pleistocene volcanoes and calderas}

The above-described technique, unfortunately, cannot be used for volcanoes that formed earlier than the Holocene, as the pre-Holocene soil-pyroclastic layers in the Kuril-Kamchatka region were almost everywhere destroyed by denudation processes during the great Late Pleistocene glaciation. In addition, deposits of this age, accumulated under cold conditions during the glaciation, are extremely poor in organic matter. However, 


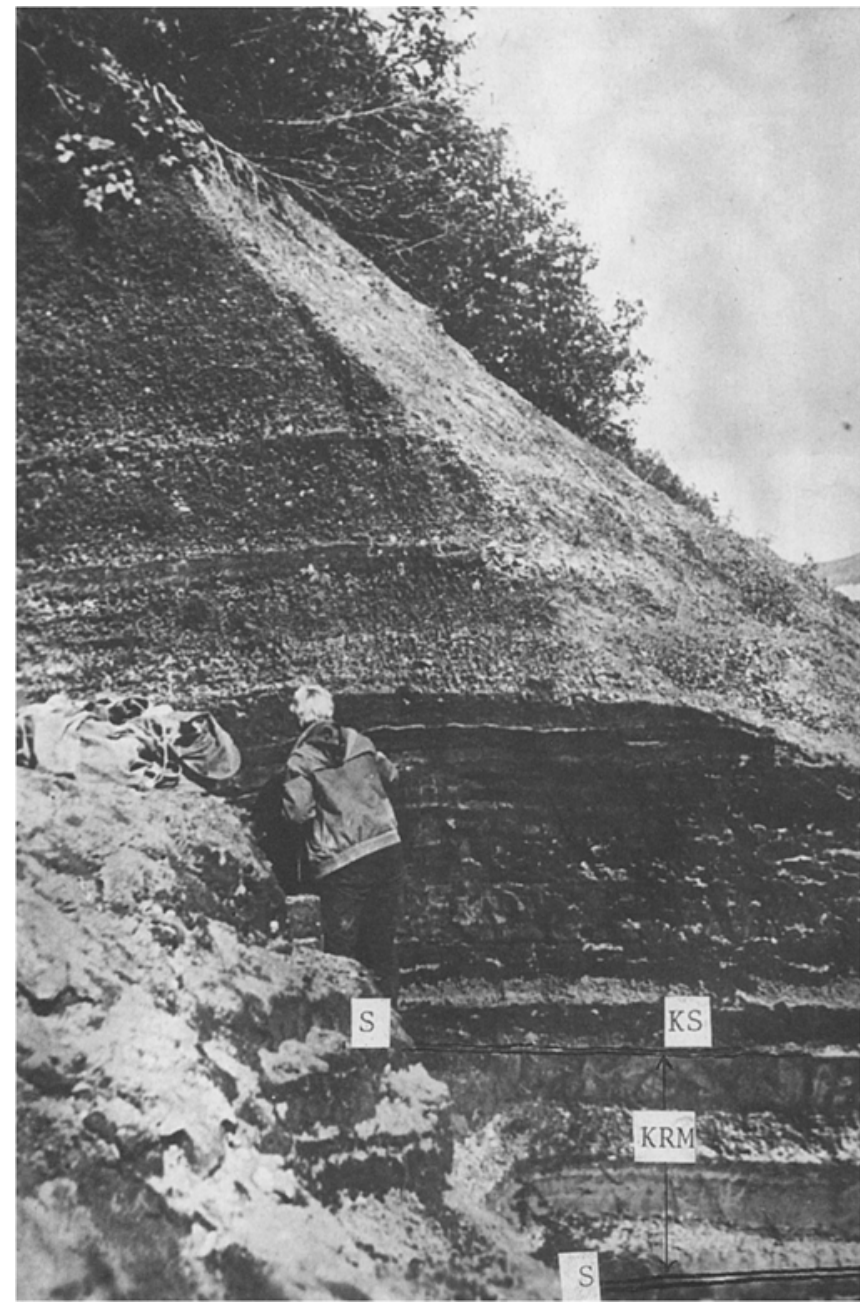

Fig. 2 Soil-pyroclastic sequence at the foot of Maly Semiachik volcano (generalized section is presented in Fig. 4). Pyroclastic deposits associated with the formation of Karymsky caldera (KRM) are seen below, pyroclastics (KS) of Maly Semiachik volcano (Kaino-Semiachik) lie above. KRM eruption and pyroclastics of early Kaino-Semiachik eruptions are dated on buried soils (S) underlying them. Above are cinders associated with the large Kaino-Semiachik eruption, which occurred about 4000 years ago

the radiocarbon method in some instances dates pyroclastic deposits from caldera-forming eruptions associated with charcoal and buried soils.

$\mathrm{K}-\mathrm{Ar}$ dating for young Pleistocene volcanic rocks was not used because of low $\mathrm{K}$ concentrations in KurilKamchatkan rocks. The fission track method is also infrequently used because the deposits are poor in apatite and zircon; only single dates obtained on volcanic glass are available (Masurenkov 1980a).

For age identification of Late Pleistocene volcanoes we use the glacial deposits of the Late Pleistocene glaciation: moraines of stage I (analogous to the Early Wisconsinian of North America) and stage II (analogous to the Late Wisconsinian). In the deposits of the Late Interglacial (Interglacial Sangamon in North America), the spore-pollen spectra indicate a warmer climate than the contemporary climate and are a good age marker in Kamchatka (Braitseva et al. 1968). Data on the absolute age of glacial and interglacial deposits in the Kuril-Kamchatka region are meager and we arbitrarily assign ages based on stratigraphic analogues in North America: stage I, 79000-65000 years; stage II, 35000-10000 years;and Late Pleistocene Interglacial, 132000-79000 years (Sibrava et al. 1986).

\section{Holocene volcanic landforms}

Holocene calderas

The ${ }^{14} \mathrm{C}$ ages of all Holocene calderas in Kamchatka and the Kuril Islands have been determined (Table 3, Figs $1 \mathrm{~B}$ and $5 \mathrm{~A}$ ).

Karymsky caldera (Fig. 6), within which Karymsky volcano is located, formed about $7700-7800$ years ago (Braitseva and Melekestsev 1991). The age of charcoal from the pumice lapilli layer at the base of the caldera pyroclastic deposits is $7700 \pm 200$ years (Table 3, Fig. 4). Ages of 7800-7900 years have been determined for the uppermost soil layer buried by these pyroclastic deposits. The date $7550 \pm 80$ years was derived from the thick soil overlying the caldera pyroclastic units and is likely to be substancially younger as it determines the mean age of the whole soil horizon (see under Study methods). Charcoals from pyroclastic flow and surge deposits are systematically older, ranging from 8000 to 8600 years (Table 3, Fig. 3). Because of the large scattering of data, we regard the dates of more than 8000 years to be too old and give preference to the concordant dates obtained on charcoals from the lapilli layer and from the underlying and overlying soils.

The Kuril Lake caldera was initially considered to be of Holocene age, because its pyroclastic deposits overlie glacial deposits of phase II of the Late Pleistocene glaciation. The radiocarbon age of the Kuril Lake caldera was previously thought to be about 8000 years (Kraevaya 1967; Masurenkov 1980b) as most age determinations on charcoal and buried soils ranged from 8000 to 8400 years. This age, however, disregarded two dates then available (obtained by L. D. Sulerzhitsky); one on underlying peat $(7860 \pm 100)$ and one on wood from this peat $(7620 \pm 50)$.

Our new dates show that the ages of underlying soils range from 7570 to 8150 years (Table 3, Fig. 3C). However, the youngest dates are $7570-7860$ years. A new charcoal age from pyroclastic flow deposits was determined to be $7770 \pm 40$ years. Previously reported dates of 8340-8400 years obtained on charcoal from the basement of the caldera pyroclastic deposits (Masurenkov 1980b) seem to be too old (Braitseva et al. 1993). The oldest dates on soils overlying the pyroclastic deposits range from 7530 to 7670 years BP, and are in good agreement with the youngest dates obtained on the soils underlying them. 


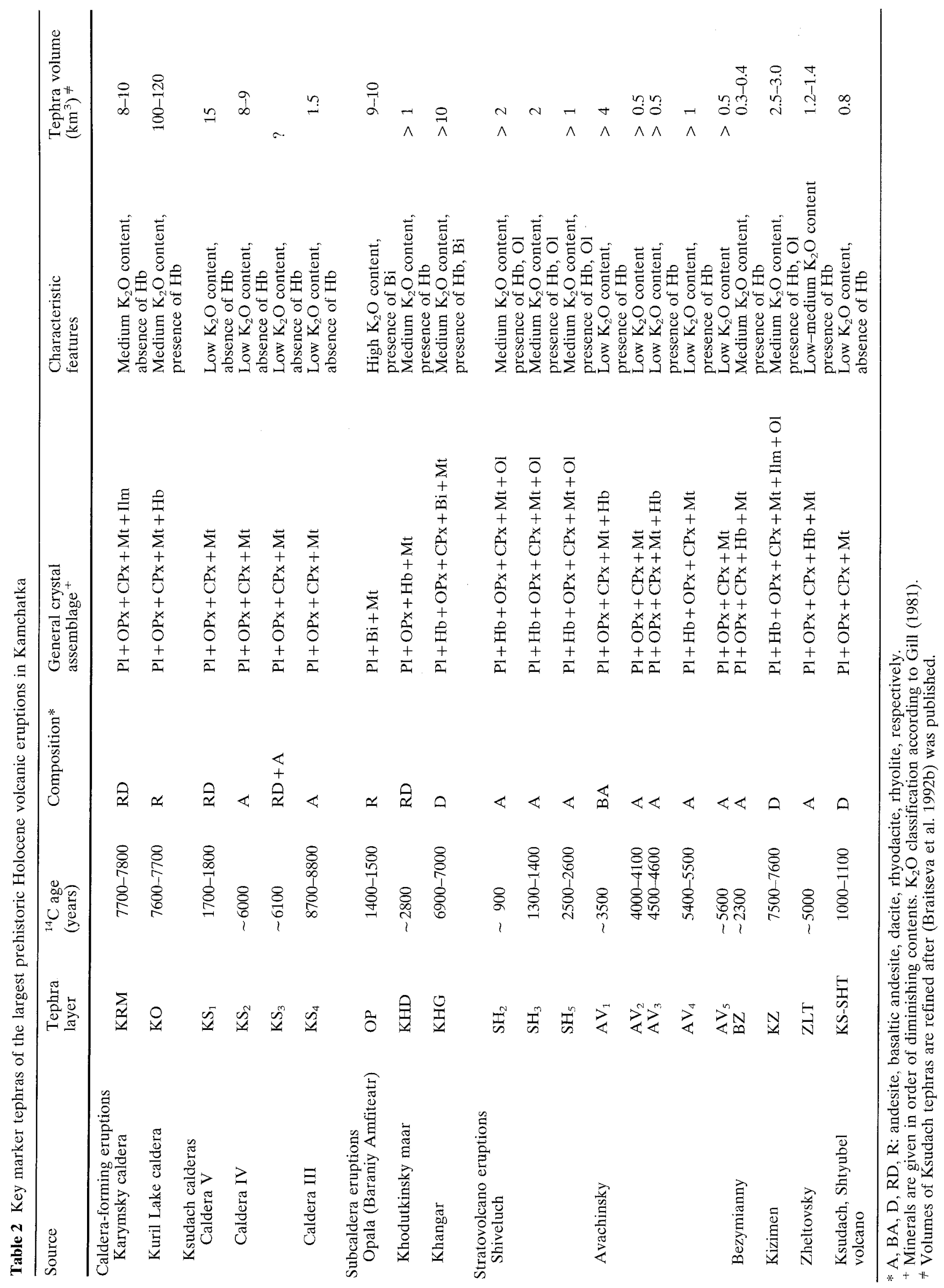



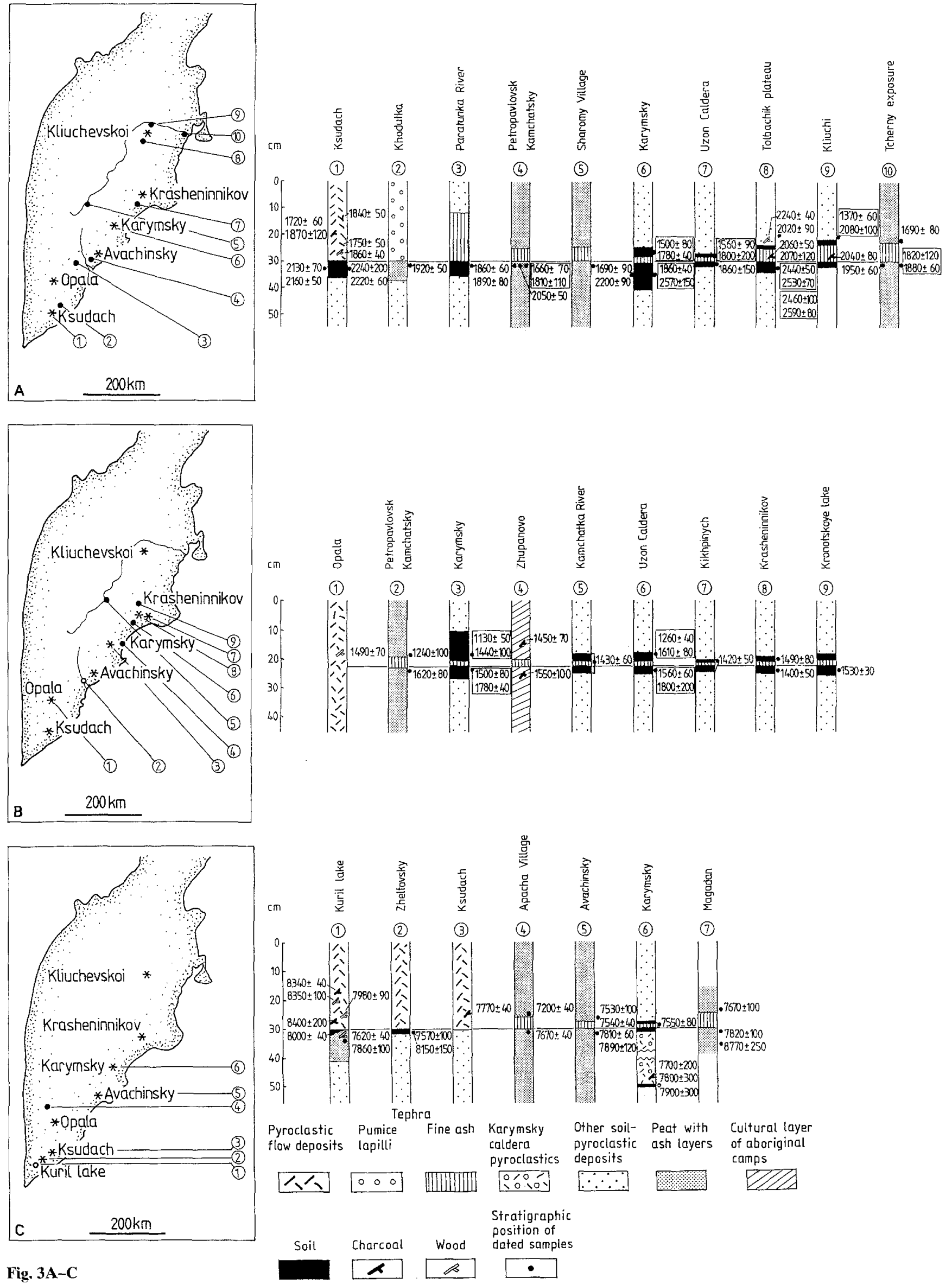

Fig. 3A-C 
Fig. 4 Generalized sections through soil-pyroclastic sequence at the foot of Karymsky and Maly Semiachik volcanoes. 1, Tephra from Karymsky; 2, tephra from Maly Semiachik; $\mathbf{3}$, pyroclastic flow deposits of Maly Semiachik; $\mathbf{4}$, marker ash layers; $\mathbf{5}$, buried soil horizons; 6 , slightly humic sandy loams; 7-11, pyroclastic deposits associated with the formation of Karymsky caldera - 7, pumice bombs; 8 , pumice lapilli; 9, stratified tephra; 10, pyroclastic flow; 11, pyroclastic surge; and 12, charcoal

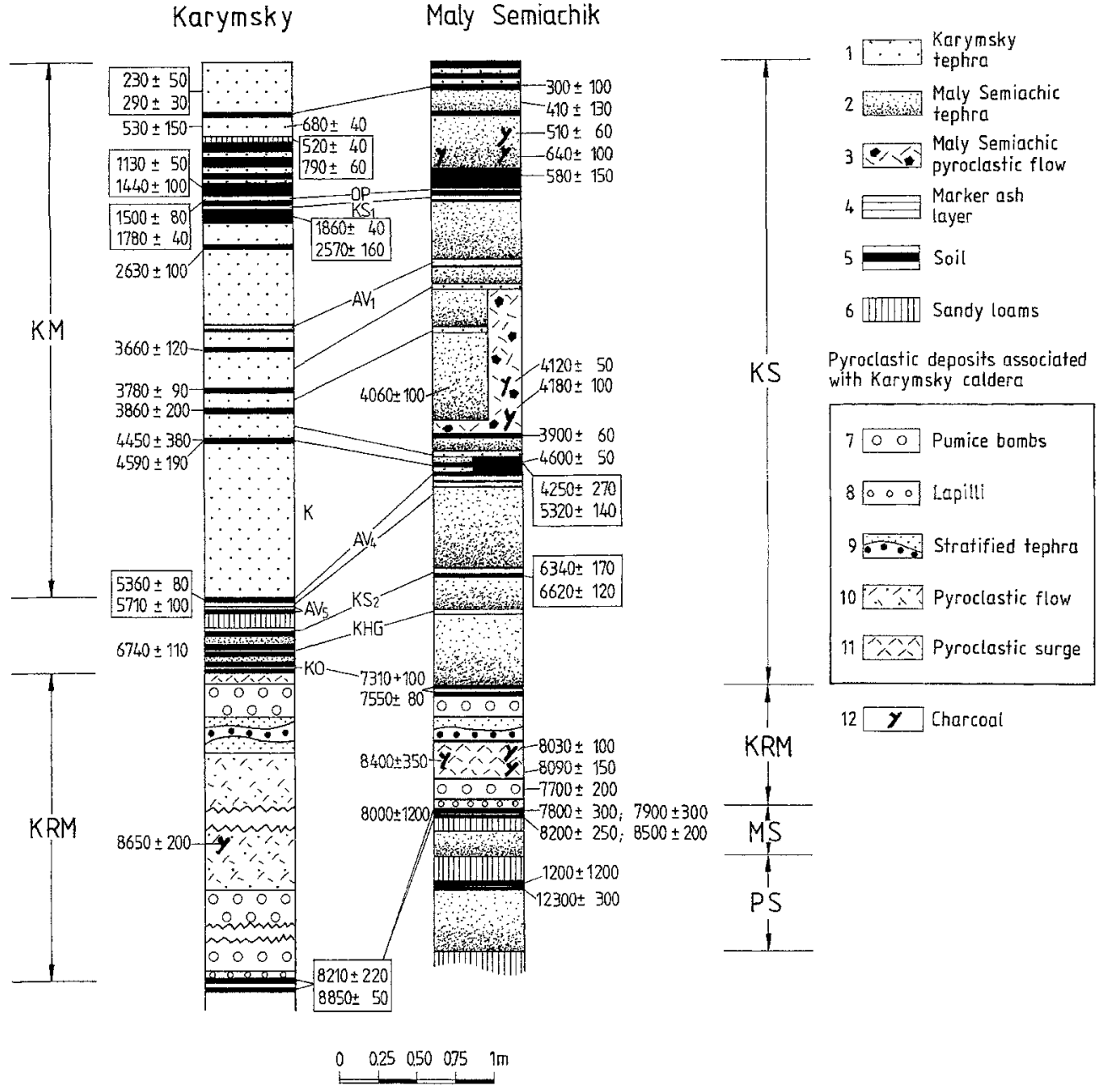

Tephrostratigraphic studies also indicate that fine ash from the Kuril Lake eruption exposed in the Karymsky volcano region lies above the Karymsky caldera pyroclastic deposits and is intercalated between the above-mentioned soils dated $7550 \pm 80$ (Fig. 3C). Thus the Kuril Lake caldera is younger than the Karymsky caldera and formed roughly $7600-7700$ years ago.

Similar dates of $7670 \pm 100$ and $7820 \pm 100$ years have been obtained on soils respectively over- and underlying the Kuril Lake tephra near Magadan city, more than $1000 \mathrm{~km}$ north-west of the source (Melekestsev et al. 1991b).

Iliinsky caldera, within which Iliinsky volcano is located, is immediately adjacent to the Kuril Lake from the east. It formed immediately alter the Kuril Lake caldera collapse as its pyroclastic deposits directly overlie those of the Kuril Lake.

\section{Calderas of the Ksudach volcanic massif}

All Holocene calderas at Ksudach volcano have been dated. The oldest (caldera III) was identified by Se-

Fig. 3 Radiocarbon dates for the pyroclastic deposits $\mathrm{KS}_{1}$ from Ksudach (caldera V) (A); OP from Baraniy Amphiteatr crater (B); KO from Kuril Lake caldera (C) lyangin (1990) and formed, according to our data, $8700-8800$ years BP as a result of the $\mathrm{KS}_{4}$ eruption. The dates on a thin carbonized soil underlying the pyroclastics from that eruption range from 8770 to 8870 years (Table 3).

The second Holocene caldera (caldera IV) at Ksudach volcano formed roughly 6000 years BP as a result of two closely spaced explosive eruptions, $\mathrm{KS}_{2}$ and $\mathrm{KS}_{3}$. In most sections, the pyroclastic layers from these eruptions directly overlie each other. Only in rare instances does a thin layer of slightly humic sandy loams occur between them. This suggests that the pyroclastic units correspond to two different eruptions separated by a short time interval. The caldera-forming eruptions $\mathrm{KS}_{2}$ and $\mathrm{KS}_{3}$ took place 6000 and 6100 years BP, respectively. The date of $6130 \pm 40$ years was obtained under the $\mathrm{KS}_{3}$ pyroclastic unit, which coincides with the date of $6130 \pm 70$ from the humic layer separating the $\mathrm{KS}_{3}$ and $\mathrm{KS}_{2}$ units. The dates from thin soils underlying the $\mathrm{KS}_{2}$ unit range from 5790 to 6130 years (Table 3) and the age of the soil overlying the ash of this eruption is $5970 \pm 100$ years. These data suggest that the eruption occurred about 6000 years BP.

Older ages shown in Table 3 (6200-6500 years) were obtained from soil underlying the $\mathrm{KS}_{2}$ tephra at long distances from the Ksudach massif near the Maly and 
Table 3 Ages of Holocene calderas and craters of subcaldera eruptions

\begin{tabular}{|c|c|c|c|c|}
\hline $\begin{array}{l}\text { Names of calderas } \\
\text { and craters }\end{array}$ & $\begin{array}{l}{ }^{14} \mathrm{C} \text { dates } \\
\text { (years) }\end{array}$ & $\begin{array}{l}\text { Laboratory } \\
\text { index }\end{array}$ & Comments & ${ }^{14} \mathrm{C}$ ages (years) \\
\hline \multicolumn{5}{|l|}{ Calderas } \\
\hline \multirow[t]{9}{*}{ Karymsky } & $7550 \pm 80$ & GIN-1047 & $b s^{1}$ & \multirow[t]{9}{*}{$7700-7800$} \\
\hline & $7700 \pm 200$ & GIN-844 & $c^{2}$ & \\
\hline & $7800 \pm 300$ & GIN-1049 & $\mathrm{bs}^{3}$ & \\
\hline & $7900 \pm 300$ & GIN-1163 & $b s^{3}$ & \\
\hline & $7920 \pm 70$ & GIN-5278 & & \\
\hline & $8030 \pm 100$ & GIN-1171 & $c^{2}$ & \\
\hline & $8090 \pm 150$ & GIN-1162a & $c^{2}$ & \\
\hline & $8400 \pm 350$ & GIN-1162 & $c^{2}$ & \\
\hline & $8650 \pm 200$ & IVAN-519 & & \\
\hline \multirow[t]{18}{*}{ Kuril Lake } & $7530 \pm 100$ & IVAN-812 & $b s^{1}$ & \multirow[t]{18}{*}{$7600-7700$} \\
\hline & $7540 \pm 40$ & GIN-6338 & $b s^{1}$ & \\
\hline & $7550 \pm 80$ & GIN-1047 & $\mathrm{bs}^{4}$ & \\
\hline & $7570 \pm 100$ & IVAN-828 & $\mathrm{bs}^{3}$ & \\
\hline & $7620 \pm 40$ & GIN-1062 & $\mathrm{w}^{3}$ & \\
\hline & $7670 \pm 40$ & GIN-5252 & $\mathrm{p}^{3}$ & \\
\hline & $7670 \pm 100$ & GIN-6085 & $\mathrm{bs}^{1}$ & \\
\hline & $7770 \pm 40$ & GIN-5689 & $c^{2}$ & \\
\hline & $7810 \pm 60$ & IVAN-822 & $\mathrm{p}^{3}$ & \\
\hline & $7820 \pm 100$ & GIN-6079 & $\mathrm{p}^{3}$ & \\
\hline & $7860 \pm 100$ & GIN-1063 & $\mathrm{p}^{3}$ & \\
\hline & $7890 \pm 120$ & GIN-6340 & $\mathrm{p}^{3}$ & \\
\hline & $7980 \pm 90$ & GIN-1061 & $\mathrm{w}^{2}$ & \\
\hline & $8000 \pm 40$ & GIN-207 & $\mathrm{bs}^{3}$ & \\
\hline & $8150 \pm 150$ & IVAN-826 & $b s^{3}$ & \\
\hline & $8340 \pm 40$ & GIN-211 & $\mathrm{c}^{2}$ & \\
\hline & $8350 \pm 100$ & GIN-728 & $w^{2}$ & \\
\hline & $8400 \pm 200$ & GIN-1060 & $\mathrm{c}^{2}$ & \\
\hline \multicolumn{5}{|l|}{ Ksudach } \\
\hline Caldera III & $8770 \pm 80$ & GIN-5686 & $\mathrm{bs}^{3}$ & \multirow[t]{3}{*}{$8700-8800$} \\
\hline & $8820 \pm 50$ & GIN-2984 & $b^{3}$ & \\
\hline & $8870 \pm 60$ & IVAN-833 & $\mathrm{bs}^{3}$ & \\
\hline \multirow[t]{10}{*}{ Caldera IV } & $5970 \pm 100$ & GIN-1176 & $b s^{1}$ & \multirow[t]{10}{*}{6000} \\
\hline & $5790 \pm 120$ & GIN-5679 & $\mathrm{bs}^{3}$ & \\
\hline & $5930 \pm 70$ & IVAN-869 & $\mathrm{p}^{3}$ & \\
\hline & $6090 \pm 100$ & GIN- 1175 & $\mathrm{p}^{3}$ & \\
\hline & $6130 \pm 70$ & IVAN-802 & $b s^{3}$ & \\
\hline & $6130 \pm 40$ & GIN-5685 & $\mathrm{bs}^{3}$ & \\
\hline & $6200 \pm 40$ & GIN-4431 & $\mathrm{p}^{3}$ & \\
\hline & $6340 \pm 170$ & IVAN-281 & $\mathrm{bs}^{3}$ & \\
\hline & $6360 \pm 60$ & GIN-5268 & $\mathrm{p}^{3}$ & \\
\hline & $6500 \pm 110$ & IVAN-712 & $\mathrm{p}^{3}$ & \\
\hline \multirow[t]{22}{*}{ Caldera V } & $1660 \pm 70$ & IVAN-397 & $\mathrm{p}^{3}$ & \multirow[t]{22}{*}{$1700-1800$} \\
\hline & $1690 \pm 80$ & GIN-6321 & $\mathrm{p}^{1}$ & \\
\hline & $1690 \pm 190$ & IVAN-705 & $\mathrm{p}^{3}$ & \\
\hline & $1720 \pm 60$ & GIN-2959 & $c^{2}$ & \\
\hline & $1750 \pm 50$ & GIN-2975 & $w^{2}$ & \\
\hline & $1780 \pm 40$ & IVAN-191 & $\mathrm{bs}^{1}$ & \\
\hline & $1800 \pm 200$ & GIN-328 & $\mathrm{bs}^{1}$ & \\
\hline & $1820 \pm 120$ & IVAN -450 & $\mathrm{p}^{3}$ & \\
\hline & $1840 \pm 50$ & GIN-2974 & $\mathrm{c}^{2}$ & \\
\hline & $1860 \pm 40$ & GIN-2975a & $w^{2}$ & \\
\hline & $1860 \pm 40$ & IVAN-193 & $\mathrm{bs}^{3}$ & \\
\hline & $1860 \pm 60$ & GIN-3156 & $\mathrm{bs}^{3}$ & \\
\hline & $1860 \pm 150$ & IVAN-331 & $\mathrm{bs}^{3}$ & \\
\hline & $1870 \pm 120$ & GIN-2959a & $c^{2}$ & \\
\hline & $1890 \pm 80$ & IVAN-639 & $p^{3}$ & \\
\hline & $1920 \pm 50$ & GIN-2991 & $p^{3}$ & \\
\hline & $1950 \pm 60$ & IVAN-556 & $\mathrm{bs}^{3}$ & \\
\hline & $2020 \pm 90$ & IVAN-70 & $\mathrm{bs}^{1}$ & \\
\hline & $2040 \pm 80$ & IVAN-121 & $c^{2}$ & \\
\hline & $2040 \pm 200$ & GIN-2980 & $b s^{3}$ & \\
\hline & $2050 \pm 50$ & GIN-1180 & $\mathrm{p}^{3}$ & \\
\hline & $2060 \pm 50$ & GIN-1858 & $\mathrm{c}^{2}$ & \\
\hline
\end{tabular}


Table 3 (Continued)

\begin{tabular}{|c|c|c|c|c|}
\hline $\begin{array}{l}\text { Names of calderas } \\
\text { and craters }\end{array}$ & $\begin{array}{l}{ }^{14} \mathrm{C} \text { dates } \\
\text { (years) }\end{array}$ & $\begin{array}{l}\text { Laboratory } \\
\text { index }\end{array}$ & Comments & ${ }^{14} \mathrm{C}$ ages (years) \\
\hline & $\begin{array}{l}2070 \pm 120 \\
2130 \pm 70 \\
2220 \pm 60 \\
2240 \pm 110 \\
2440 \pm 50\end{array}$ & $\begin{array}{l}\text { IVAN-57 } \\
\text { GIN-2959 } \\
\text { GIN-2976 } \\
\text { IVAN-36 } \\
\text { IVAN-82 }\end{array}$ & $\begin{array}{l}c^{2} \\
b s^{3} \\
b s^{3} \\
c^{1} \\
b s^{3}\end{array}$ & \\
\hline Tao-Rusyr & $7500 \pm 80$ & KSM-438 III & $c^{2}$ & 7500 \\
\hline Lvinaya Past & $9400 \pm 60$ & GIN-325 & $c^{2}$ & 9400 \\
\hline $\begin{array}{l}\text { Craters } \\
\text { Baraniy Amfiteatr } \\
\text { (Opala volcano) }\end{array}$ & $\begin{array}{l}1400 \pm 50 \\
1420 \pm 50 \\
1430 \pm 60 \\
1440 \pm 100 \\
1450 \pm 70 \\
1490 \pm 80 \\
1490 \pm 70 \\
1500 \pm 80 \\
1530 \pm 30 \\
1550 \pm 100 \\
1560 \pm 90\end{array}$ & $\begin{array}{l}\text { IVAN-317 } \\
\text { IVAN-372 } \\
\text { IVAN-467 } \\
\text { IVAN-189 } \\
\text { IVAN-171 } \\
\text { IVAN-316 } \\
\text { GIN-1034 } \\
\text { IVAN-191 } \\
\text { GIN-3026 } \\
\text { IVAN-172 } \\
\text { IVAN-328 }\end{array}$ & $\begin{array}{l}\mathrm{bs}^{3} \\
\mathrm{bs}^{4} \\
\mathrm{bs}^{4} \\
\mathrm{bs}^{1} \\
\mathrm{c}^{1} \\
\mathrm{bs}^{1} \\
\mathrm{c}^{2} \\
\mathrm{bs}^{3} \\
\mathrm{bs}^{3} \\
\mathrm{c}^{3} \\
\mathrm{bs}^{3}\end{array}$ & $1400-1500$ \\
\hline & $\begin{array}{l}1610 \pm 80 \\
1620 \pm 80\end{array}$ & $\begin{array}{l}\text { IVAN-323 } \\
\text { IVAN-399 }\end{array}$ & $\begin{array}{l}\mathrm{bs}^{\mathrm{t}} \\
\mathrm{p}^{3}\end{array}$ & \\
\hline Khodutkinsky 'Maar' & $\begin{array}{l}2800 \pm 40 \\
2850 \pm 120 \\
2960 \pm 120\end{array}$ & $\begin{array}{l}\text { GIN-4934 } \\
\text { GIN-2291 } \\
\text { GIN-4935 }\end{array}$ & $\begin{array}{l}p^{3} \\
p^{3} \\
p^{3}\end{array}$ & 2800 \\
\hline Khangar & $\begin{array}{l}6740 \pm 70 \\
6850 \pm 90 \\
6910 \pm 120 \\
6930 \pm 80 \\
6960 \pm 80 \\
7040 \pm 170 \\
7080 \pm 170 \\
7080 \pm 120 \\
7140 \pm 100 \\
7150 \pm 80\end{array}$ & $\begin{array}{l}\text { IVAN-573 } \\
\text { IVAN-86 } \\
\text { GIN-3028 } \\
\text { GIN-5289 } \\
\text { IVAN-319 } \\
\text { GIN-5270 } \\
\text { IVAN-688 } \\
\text { IVAN-228 } \\
\text { GIN-5288 } \\
\text { IVAN-692 }\end{array}$ & $\begin{array}{l}\mathrm{c}^{1} \\
\mathrm{w}^{3} \\
\mathrm{c}^{2} \\
\mathrm{p}^{3} \\
\mathrm{c}^{2} \\
\mathrm{p}^{3} \\
\mathrm{bs}^{3} \\
\mathrm{bs}^{3} \\
\mathrm{p}^{1} \\
\mathrm{bs}^{1}\end{array}$ & $6900-7000$ \\
\hline
\end{tabular}

Notes: c, charcoal; w, wood; p, peat; and bs, buried soil. Indices in column 4 show the stratigraphic position of the dated organic matter: 1,2,3, respectively, over, in and under the pyroclastic deposits; and 4, soil or peat enclosing tephra layer. Indices of Laboratories: IVAN, Institute of Volcanic Geology and Geochemistry, Petropavlovsk-Kamchatsky; GIN, Geological Institute, Moscow; KSM, Geochemical Institute, Moscow. Dates which were too old to be used for age estimations are separated by a blank line; see explanations in the text.

Bolshoy Semiachik volcanoes and in the Uzon caldera. Although there is no unambiguous explanation of this, the peat and soil layers may have formed over a long period of time and the dates obtained represent the average values for the whole layer rather than for its upper part.

The date of $4910 \pm 300$ years (GIN-2978, for explanation of laboratory indices see Table 3 ) from under the pyroclastics $\mathrm{KS}_{2}$ (Melekestsev and Sulerzhitsky 1990 ) is significantly younger and contradicts the whole series of dates obtained. The invalidity of this date is supported by data implying that the ash $\mathrm{KS}_{2}$ lies in sections below the ash from the Avachinsky volcano, with the age of 5400-5500 years (Fig. 7).

The third Holocene caldera (caldera V) formed 1700-1800 years ago. The tephra from this eruption $\left(\mathrm{KS}_{1}\right)$ is traced for more than $1000 \mathrm{~km}$ north of the caldera. Earlier (Piyp 1956; Gushchenko 1965; Braitseva et al. 1984, 1989b), this tephra north of Kronotskoe
Lake was mistakenly associated with the Shiveluch eruption (designated by index $\mathrm{SH}_{4}$ ). However, ensuing detailed studies in the region of Shiveluch volcano and direct field correlation have demonstrated that this tephra is a fine ash $\left(\mathrm{KS}_{1}\right)$ from the caldera-forming eruption of Ksudach volcano. At present, about 30 dates are available for pyroclastic deposits related to that eruption (Fig. 3A, Table 3). Dates ranging from 1720 to $1870 \mathrm{BP}$ have been obtained on charcoal and wood in pyroclastic flow deposits near the caldera. Dates obtained on the soil and peat underlying the caldera pyroclastics and tephra range from 1660 to 2400 years BP; the younger of them (1660-1890 BP) are in good agreement with the above-mentioned dates on charcoal and wood. Dates ranging from 1690 to $1800 \mathrm{BP}$ on the soil and peat overlying tephra $\mathrm{KS}_{1}$ also indicate that the eruption took place $1700-1800 \mathrm{BP}$. When the soil underlying the tephra (sections 1, 4 and 6 in Fig. $3 \mathrm{~A})$ gives older ages (2000-2200 BP), it must have been 


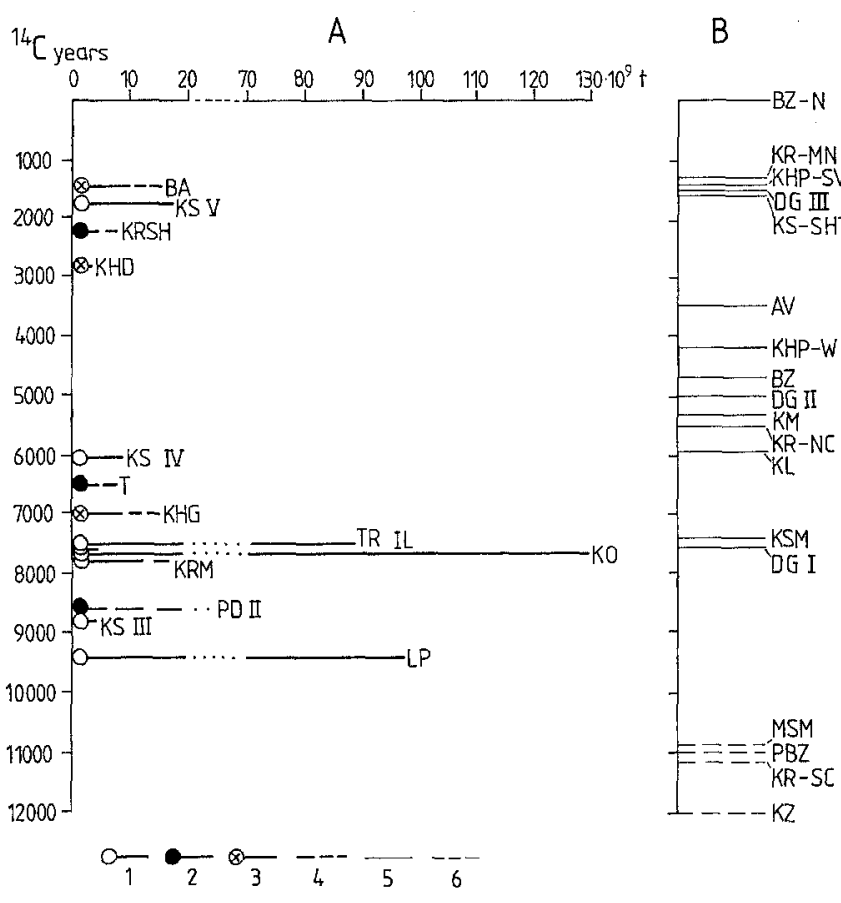

Fig. 5 Age and mass of erupted products of Holocene calderaforming and subcaldera eruptions (A) and onset of the formation of active volcanoes (B). 1, Krakatoa-type caldera-forming eruptions and related mass of pyroclastics; $\mathbf{2}$, eruptions resulted in Hawaiian-type calderas; $\mathbf{3}$, subcaldera eruptions; $\mathbf{4}$, presumed mass of ejecta; 5 and $\mathbf{6}$, onset of active volcanoes formation -5, established; 6, assumed. Indices: BA, Baraniy Amfiteatr crater (Opala volcano); KS, calderas of Ksudach massif; KRSH, caldera on Krasheninnikov volcano; KHD, Khodutkinsky 'Maar' crater; T, Plosky Tolbachik caldera; KHG, Khangar crater; TR, Tao-Rusyr caldera; KO, Kuril Lake caldera; IL, Iliinsky caldera; KRM, Karymsky caldera; PD II, Plosky Dalny II caldera; and LP, Lvinaya Past' caldera. Volcanoes: BZ, Bezymianny; BZ-N, Novy Dome; PBZ, Pre-Bezymianny; Krasheninnikov volcano: KR-MN, Mid North cone; KR-NC, North cone; KR-SC, South cone; Kikhpinych volcano: KHP-SV, Savich cone; KHP-W West cone; DG, Dikiy Greben; KS-SHT, Shtyubel cone; KZ, Kizimen volcano; AV, young cone of Avachinsky volcano; KM, Karymsky; KL, Kliuchevskoi; KSM, Kaino-Semiachik; and MSM, Meso-Semiachik

formed over a long period of time and the dates obtained show the mean age of the whole soil horizon. We note that dates in sections 8 and 9 differ. Dates of about $2000 \mathrm{BP}$ and older have been obtained here on soils not only underlying the ash, but also overlying it, as well as on charcoals and wood. Just within the Kliuchevskoi volcano group the age of this ash, previously called $\mathrm{SH}_{4}$, was derived to be roughly $2000 \mathrm{BP}$ (Braitseva et al. 1984). However, outside the Kliuchevskoi volcano group further north-east, we again obtain dates of 1700-1800 years BP for the same ash (section 10). The reason for the older ages in the region of the Kliuchevskoi volcano group remains obscure.

Ages were also determined for several large Holocene 'Hawaiian-type' calderas formed in Kamchatka. The younger caldera at the summit of Plosky Dalny is associated with the formation of large lava flows and cinder cones at the foot of the volcano (Lavovy Shysh cone group) and its age is roughly 8600 years. Lavas from these eruptions overlie the moraine of stage II of the Late Pleistocene glaciation; the age of soil underlying the pyroclastics from these eruptions is $8610 \pm 60$ (GIN-7403) and the age of soil overlying it is $8620 \pm 100$ years (IVAN-674). The caldera at Plosky Tolbachik apparently formed about 6500 years ago as a response to profuse lava outflows and subsynchronously with a large sector collapse at Ostry Tolbachik volcano (Melekestsev and Braitseva 1988). The associated debris avalanche deposits lie in a soil-pyroclastic sequence above the marker ash KHG, with an age of 6900-7000 years. The caldera at the North cone of Krasheninnikov volcano formed about 2200-2400 years ago as a result of large eruptions of andesitic lavas and tephra (Ponomareva 1990). The dates of $2240 \pm 60$ (GIN-3023) and $2440 \pm 70$ years (IVAN-318) were obtained for soil separating these tephra units.

Two 'Krakatoa-type' calderas formed in the Holocene in the Kuril Islands. Tao-Rusyr caldera formed roughly 7500 years ago as a series of radiocarbon dates, the youngest of which is $7500 \pm 80$ years, were obtained on charcoals from pyroclastic flow deposits associated with this caldera (Melekestsev et al. 1974b). The latter are underlain by the Kuril Lake tephra aged 7600-7700 years BP (Table 2). Lvinaya Past' caldera apparently formed about $9400 \pm 60$ years BP, as indicated by a date on charcoal from a pyroclastic unit produced by the caldera-forming eruptions.

\section{Craters of subcaldera eruptions}

In Kamchatka there are three large craters that produced large volumes of pyroclastics comparable with those of the caldera-forming eruptions. The pyroclastic deposits include pyroclastic flows and tephras that can be traced for tens and hundreds of kilometers. At the final stage of such eruptions, extrusive domes commonly grow within the craters. Such craters have no distinct signs of coffapse and may be located either near the base of the volcanoes or at their summits. The eruptions that resulted in the formation of such craters were named 'subcaldera eruptions' (Melekestsev et al. 1991a). An historical analog to such eruptions is the Novarupta eruption of 1912.

Baraniy Amfiteatr crater $(1.3 \times 2 \mathrm{~km}$, Fig. 8$)$ formed as a result of the great eruption which produced more than $10 \mathrm{~km}^{3}$ of rhyolite pyroclastic material about 1400-1500 years BP (Melekestsev et al. 1991a). The crater is located at the foot of Opala volcano. Carbonized wood from the pyroclastic deposits in the proximity of the crater was dated as $1490 \pm 70$ years (Sheimovich and Patoka 1979). Soils buried by tephra from that eruption yielded ages of $1400-1560$ years and soils overlying this tephra 1440-1490 years (Fig. 3B, Table 3 ). The dates of $1610 \pm 80$ from under the tephra and $1240 \pm 100$ (IVAN-400) from above it (section 2, Fig. $3 B$ ) seem to show the mean age of thick peat layers and 
Fig. 6 Holocene Karymsky caldera and the younger Karymsky volcano. Late Pleistocene Karymsky Lake caldera and Upper Pleistocene dissected pyroclastic cover are in the background. View to south. Photo by V. A. Podtabachny

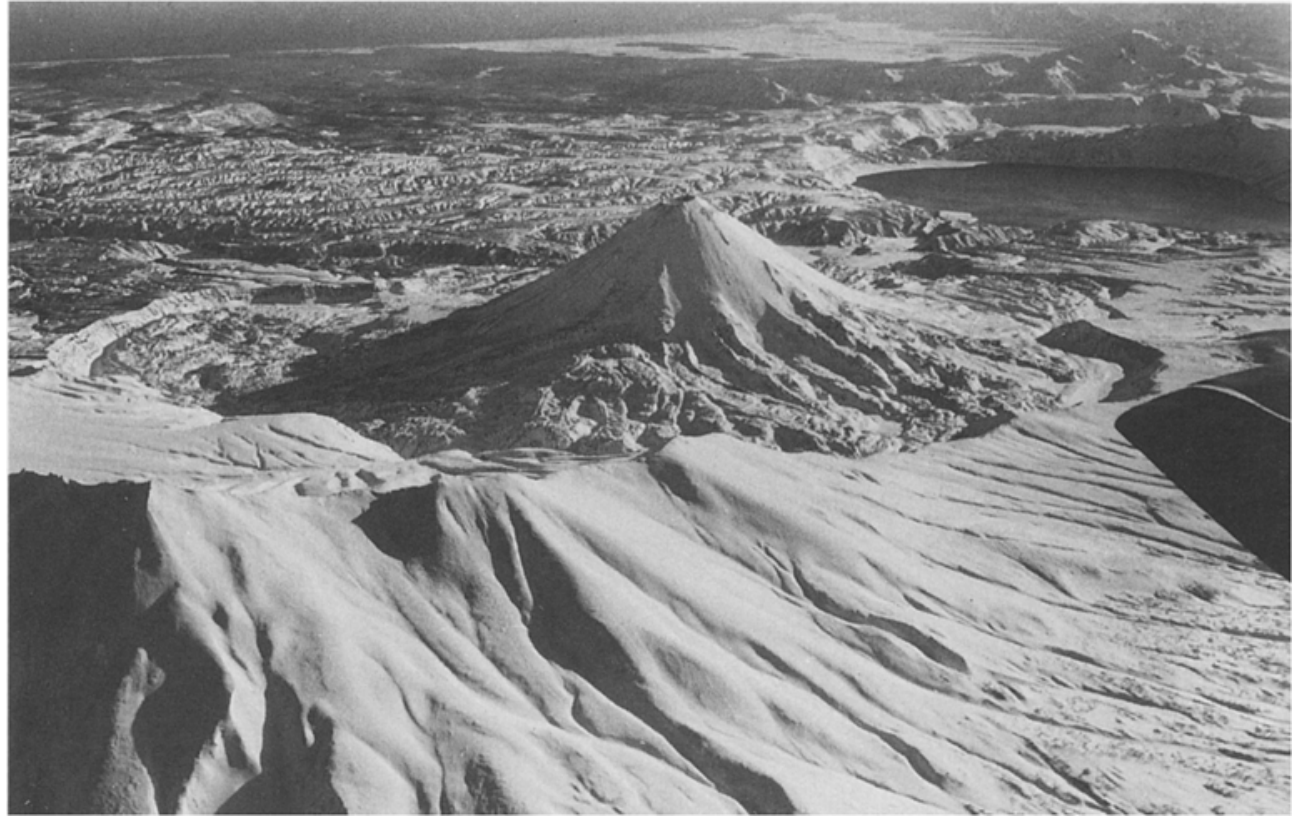

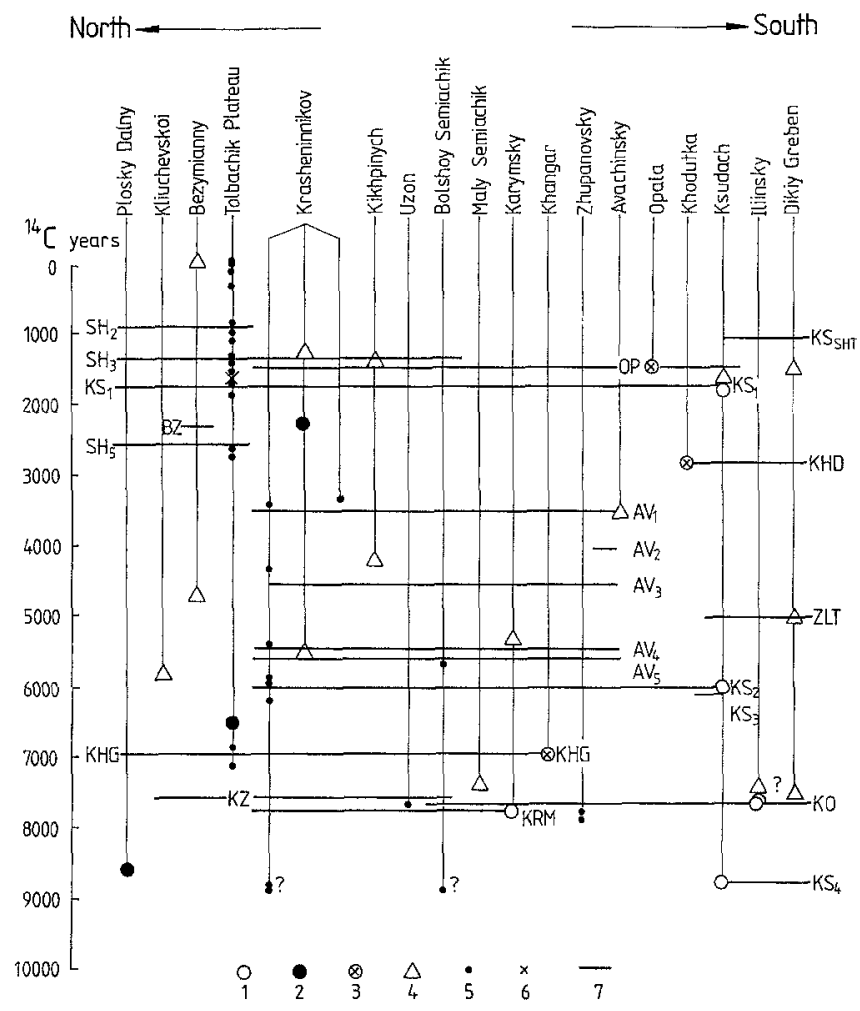

Fig. 7 Ages of Holocene stratovolcanoes, calderas and craters of subcaldera eruptions and monogenic forms of Kamchatka and their correlation with tephra marker layers. 1, Krakatoa-type calderas; 2, Hawaiian-type calderas; 3, craters of subcaldera eruptions; 4 , stratovolcanoes (onset of their formation); $\mathbf{5}$, monogenic forms (cinder cones, extrusive domes, maars); $\mathbf{6}$, onset of supply of magnesian basalts in the Tolbachik zone of cinder cones; and $\mathbf{7}$, tephra marker layers (see indices in Table 2, lines for ashes correspond to the true area of their dispersal) show, respectively, older and younger ages. An age on charcoal from the cultural layer of aboriginal camps in the settlement of Zhupanovo over the Baraniy Amfiteatr ash layer is $1450 \pm 70$ and, under this ash, $1550 \pm 100$ years (Braitseva et al. 1987).

Khodutkinsky Maar crater, with a diameter of $0.9 \mathrm{~km}$, is located at the base of Khodutkinsky volcano. The eruption associated with this crater produced more than $1 \mathrm{~km}^{3}$ of rhyolite-dacite pumice pyroclastics. The crater age is about 2800 years based on three dates on peat and soil underlying tephra from that eruption (Table 3).

A large crater $(2.5 \times 2 \mathrm{~km})$ at the summit of Khangar volcano is also a result of a subcaldera eruption. The total volume of dacite pyroclastic deposits produced by this eruption, including tephra and pyroclastic flows, was probably more than $10 \mathrm{~km}^{3}$. Charcoal ages from pyroclastic flows produced by that eruption were $6460 \pm 135$ years (MO-169, Braitseva et al. 1974). In recent years, numerous new dates have been obtained for tephra from that eruption, which suggest the age of the Khangar crater to be $6900-7000$ years. Charcoals from the ash layer as well as peat and soils underlying it yield ages of 6850-7080 years (Table 3). Carbonaceous interbeds, soils and peat over this ash have ages $6740 \pm 70,7150 \pm 80$ and $7140 \pm 100$ years.

\section{Holocene stratovolcanoes}

The ages of Holocene stratovolcanoes (Figs 1B, 5 and 9) were obtained through detailed geological and tephrochronological studies which included: (1) mapping of volcanic landforms; (2) measuring of soil-pyroclastic sections and compiling a summary section through the Holocene tephra deposits; and (3) dating of all mapped landforms (lava and pyroclastic flows, debris aval- 
Fig. 8 Opala volcano and Baraniy Amfiteatr crater. View to north-west. Photo by V. N. Dvigalo

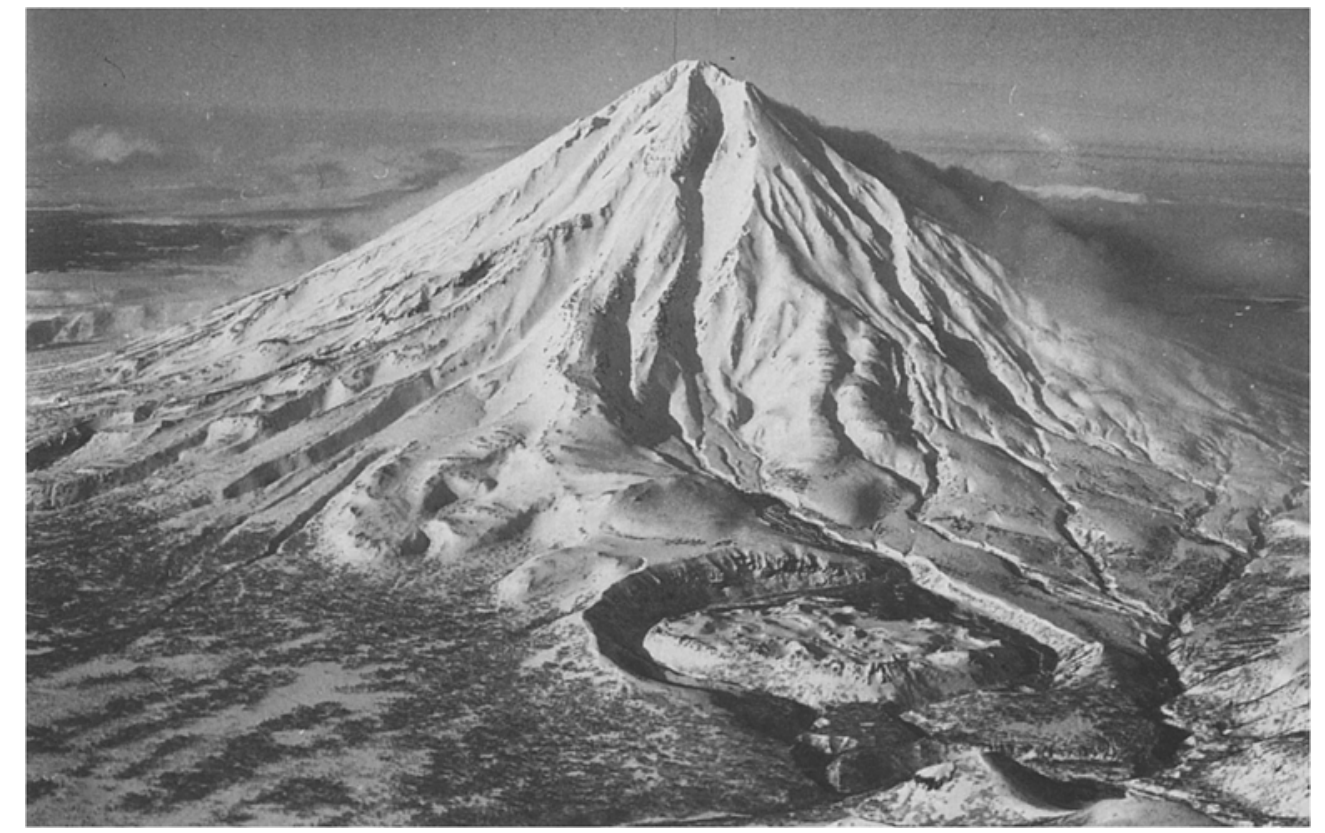

anches, etc.) through the study of the overlying tephra layers and compiling a summary section including all the deposits of a volcano. Then, the eruptive history of a volcano being reconstructed, we can identify the deposits of the earliest eruptions of each cone and date them by the radiocarbon method on associated organic matter (Table 4), or by correlation with the tephra marker beds (Fig. 7).

The age of Kliuchevskoi (Fig. 10) was previously reported to be about 6100 years based on the rate of soilpyroclastic cover accumulation between the cinder from its earliest eruptions and dated marker ash layers (Melekestsev et al. 1990). New radiocarbon dates (Table 4) suggest that Kliuchevskoi volcano began to form between 5800 and 6000 years BP.

The age of Bezymianny stratovolcano is about 4700 years, as shown by the position of tephra from its earliest eruptions in soil-pyroclastic sequences between dated marker ashes from Shiveluch $\left(\mathrm{SH}_{5}\right)$ and Khangar (KHG) volcanoes (Braitseva et al. 1991). The approximate age of the volcano was determined using the calculated rate of sandy loam accumulation between these marker ashes. An older pre-Bezymianny volcano, a fragment of which was preserved in the south-eastern part of the edifice, formed about 11000 years ago and stopped its activity about 7000 years ago. Its tephra was found in a soil-pyroclastic sequence within the interval between the base of the section with a date of $10700 \pm 200$ years and marker ash KHG (6900-7000 years BP). Of special interest is the Novy dome, which started to grow in the crater of Bezymianny after its well-known eruption of 1955-1956. We consider the Novy dome as the third volcano, or 'Neo-Bezymianny'. The style of its activity (high explosive activity, repeated lava outflows and very high production rate) is typical of the onset of stratovolcano formation (Braitseva et al. 1991), which suggests that this is the initial phase of a new large andesitic volcano, rather than the growth of a typical (small) extrusive dome. It is noteworthy that this volcano started to form after a prolonged repose period lasting for about 1000 years.

Kizimen volcano started to form at the boundary between the Late Pleistocene and Holocene. Pyroclastic flow deposits from one of the first large eruptions of this volcano lie at the base of the Holocene soil-pyroclastic sequence immediately on the moraine deposits of stage II. Dates obtained in the section above these pyroclastics are $9190 \pm 150$ and $8940 \pm 150$ years. However, study of sections of the volcano demonstrates that the eruption of this pyroclastic flow was preceded by a period of intensified activity with outpourings of lava and block and ash flows and the growth of an extrusive dome, which suggests that this volcano started to form at the end of the Late Pleistocene, roughly 1100012000 years ago (Melekestsev et al. 1995).

Estimates of age were made for three edifices that make up the massif of Krasheninnikov volcano (Ponomareva 1990). The South cone began to form no later than 11000 years ago, as cinders produced during the earliest stages of its activity are intercalated in the moraine deposits of stage II and immediately overlie them. A date of $9320 \pm 40$ years was obtained on peat in the section substantially stratigraphically higher than these cinders. The South cone activity ended about 6500 years ago, as tephra from its most recent eruption lies between marker ash KHG and peat with an age of $6200 \pm 40$ years.

The North cone started to form 5500 years ago based on dates obtained from peat and soil immediately beneath and over the cinders from its earliest eruption (Table 4) and confirmed by their stratigraphic position between the marker ashes from Avachinsky volcano $\left(\mathrm{AV}_{4}\right.$ dated at 5400-5500 years and $A V_{5}$ dated at 5600 years, Table 2, Fig. 7). 

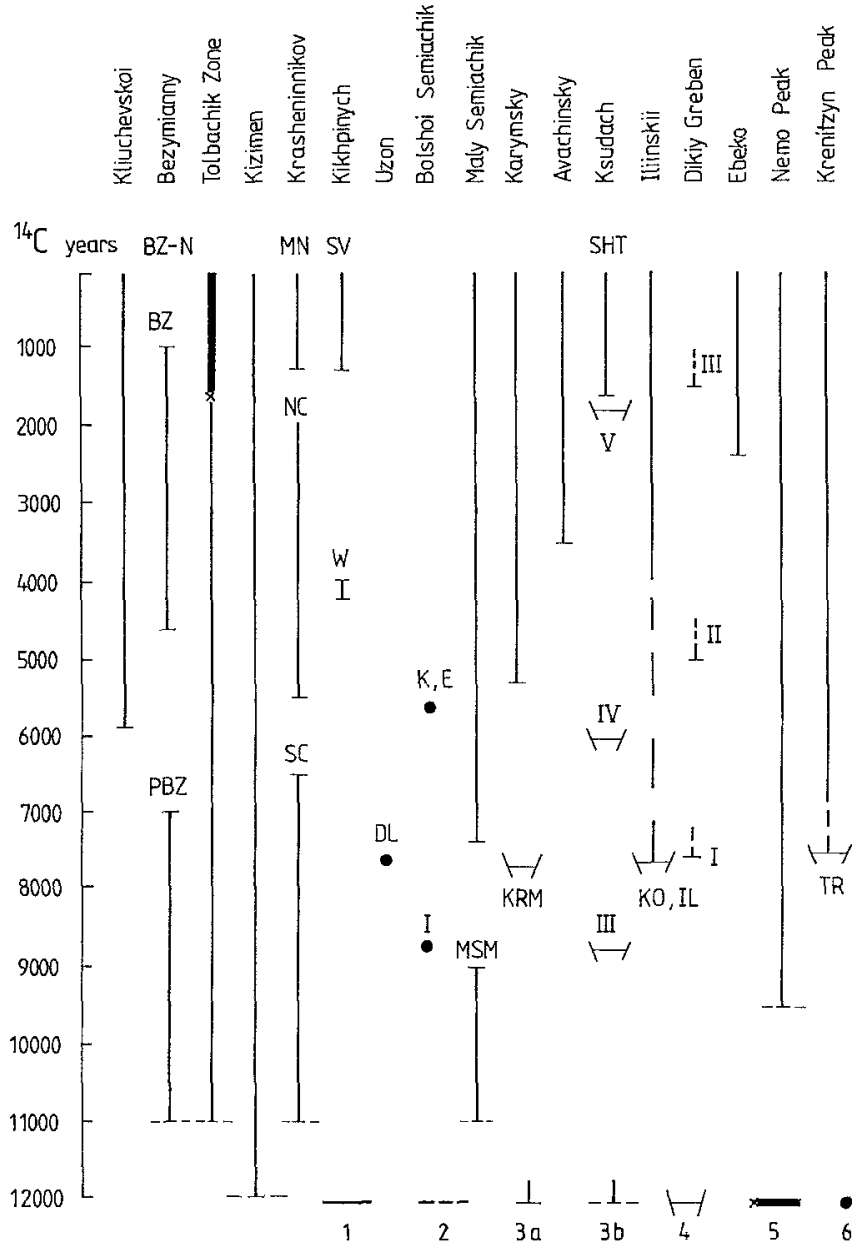

Fig. 9 Ages of Holocene volcanoes and calderas. 1-2, Period of volcano formation: $\mathbf{1}$, established; $\mathbf{2}$, assumed; $\mathbf{3}$, onset and end of volcano formation (horizontal lines) - a, established; $\mathbf{b}$, assumed; 4, calderas; $\mathbf{5}$, time of intense supply of magnesian basalts and large cinder cone formation in the Tolbachik zone; and $\mathbf{6}$, monogenetic eruptive centers. Indices: DL, Dalnee Lake maar; extrusive domes - I, Ivanov; K, Korona; and E, Ezh. Other indices as in Fig. 5

The Mid-North cone located inside the North cone summit caldera formed about 1300 years ago. This is supported by the date of $1300 \pm 120$ years obtained on charcoal immediately under cinders from the earliest eruptions of the cone, as well as by the stratigraphic position of volcanics from these eruptions immediately over the marker ash $\mathrm{SH}_{3}$ with an age of 1300-1400 years (Fig. 7).

Young Kikhpinych volcano formed in the mid-Holocene and is separated from the ancient extinct Old Kikhpinych (Mount Peak) by a repose period which lasted for a few tens of thousands of years. The radiocarbon age of the first West cone was taken to be 4000 years (Braitseva et al. 1989a). New dates of $4240 \pm 40$ years obtained on peat under the pyroclastic deposits of this cone and $4080 \pm 50$ on soil over them suggest that the cone formed within a 200 year period between 4200 and 4000 years ago. The second cone, Savich cone, began to form 1400 years ago after nearly more than a
2500 year repose period. This is supported by the dates obtained on soils buried by pyroclastics from its earliest eruptions (Table 4) and by the stratigraphic position of this pyroclastic unit between the marker ashes $\mathrm{SH}_{3}$ and OP (Table 2, Fig. 7). Fumarolic activity at Savich cone is still observed.

Detailed tephrochronological studies (Braitseva et al. 1980) allow an age determination of all three cones of Maly Semiachik volcano. The first cone, Paleo-Semiachik, began to form about 20000 years ago, as estimated from the average production rate of the volcano (Selyangin et al. 1979). Pyroclastic deposits from three Maly Semiachik cones (PS, Paleo-Semiachik; MS, Meso-Semiachik; and KS, Kaino-Semiachik), can be seen in the soil-pyroclastic sequence at the base of Maly Semiachik volcano (right column, Fig. 4). Buried soils fix the periods of repose between the formation of these cones (Figs 2 and 4). Paleo-Semiachik ceased its activity earlier than 12000 years ago, which is supported by the dates from the soils overlying its pyroclastic deposits (Table 4). The middle Meso-Semiachik cone began to grow about 11000 years ago as its pyroclastic deposits overlie the above-mentioned 12000 year old soils, and completed its activity about 9000 years ago. The date of $8500 \pm 200$ years was determined on the soil horizons overlying its pyroclastics. The youngest Kaino-Semiachik active cone formed 73007400 years ago based on the dates from the soil underlying the pyroclastic deposits from its earliest eruptions (Table 4). These pyroclastics lie between the marker tephra layers KHG and KO (Table 2), closer to the latter.

Karymsky volcano (Fig. 6) began to form within the Karymsky caldera about 5300 years ago (Braitseva and Melekestsev 1991). The profuse pumice pyroclastic unit KRM associated with the formation of the caldera can be seen in the soil-pyroclastic sequence (Figs 2 and 4). This pyroclastic unit is overlain by a thick package of soils that contains thin marker ashes and records a 2400 years long period of quiescence after the caldera-forming eruption. These soils are overlain by the pyroclastic deposits KM from Karymsky volcano, which formed inside the caldera; the layer $\mathrm{K}$ is tephra from its earliest eruptions. The youngest dates for soils underlying layer $\mathrm{K}$ are $5280 \pm 120$ and $5360 \pm 80$ years. This is in good agreement with the position of this layer immediately over the marker ash $\mathrm{AV}_{4}$ (Table 2, Fig. 7) dated at $5400-5500$ years.

The yound cone of Avachinsky volcano started to form about 3500 years ago. Charcoals from pyroclastic flow and surge deposits of this eruption have an age of $3570 \pm 40$ and $3510 \pm 100$ years, and dates for buried soils underlying these deposits are $3560 \pm 50$ and $3580 \pm 90$ years. The marker tephra layer $\mathrm{AV}_{1}$ (Table 2) is associated with the earliest eruption of the young cone of Avachinsky volcano.

Gorely volcano probably started to form during the second stage of the Late Pleistocene glaciation. This is based on the atypically great thickness and specific 
Table 4 Radiocarbon dates for the onset and completion of the Holocene volcanic cones formation in the KurileKamchatka region

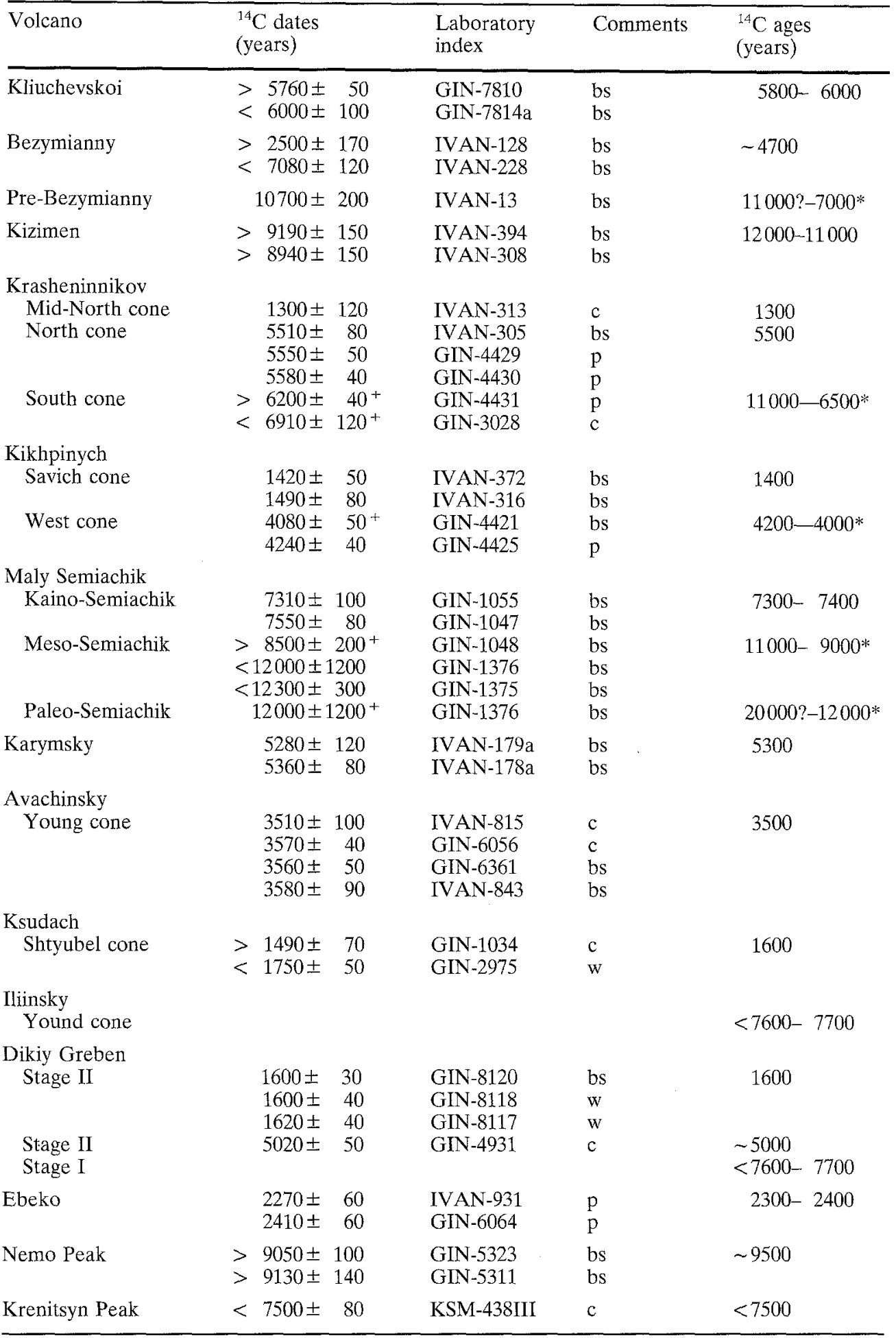

All ${ }^{14} \mathrm{C}$ dates are given for the onset of volcano formation, except for the dates with sign ${ }^{+}$, which indicates the completion of cone formation. Ages with sign * designate the end of cone life; the rest imply the onset of volcano formation (see text). Other symbols as in Table 3. morphology of very high and steep frontal cliffs of basaltic-andesite lava flows from the earliest eruptions, which are probably due to ponding against the glacier.

Shtyubel cone in caldera $\mathrm{V}$ of Ksudach massif began to form about 1600 years ago. Tephra from its earliest eruptions lies between the $\mathrm{KS}_{1}$ pyroclastic deposits
(1700-1800 years) and the ash marker bed OP dated at 1400-1500 years (Fig. 7). The large crater at the summit of Shtyubel cone first formed 1000-1100 years ago during an eruption that produced more than $1 \mathrm{~km}^{3}$ of tephra (KS-SHT, Table 2). Radiocarbon dates for peat and carbonized soil under tephra from this eruption are 
Fig. 10 Kliuchevskoi volcano and cinder cones of its flank eruptions. Bezymianny volcano with its fume cloud is on the distant left. View to southwest. Photo by V. A. Podtabachny

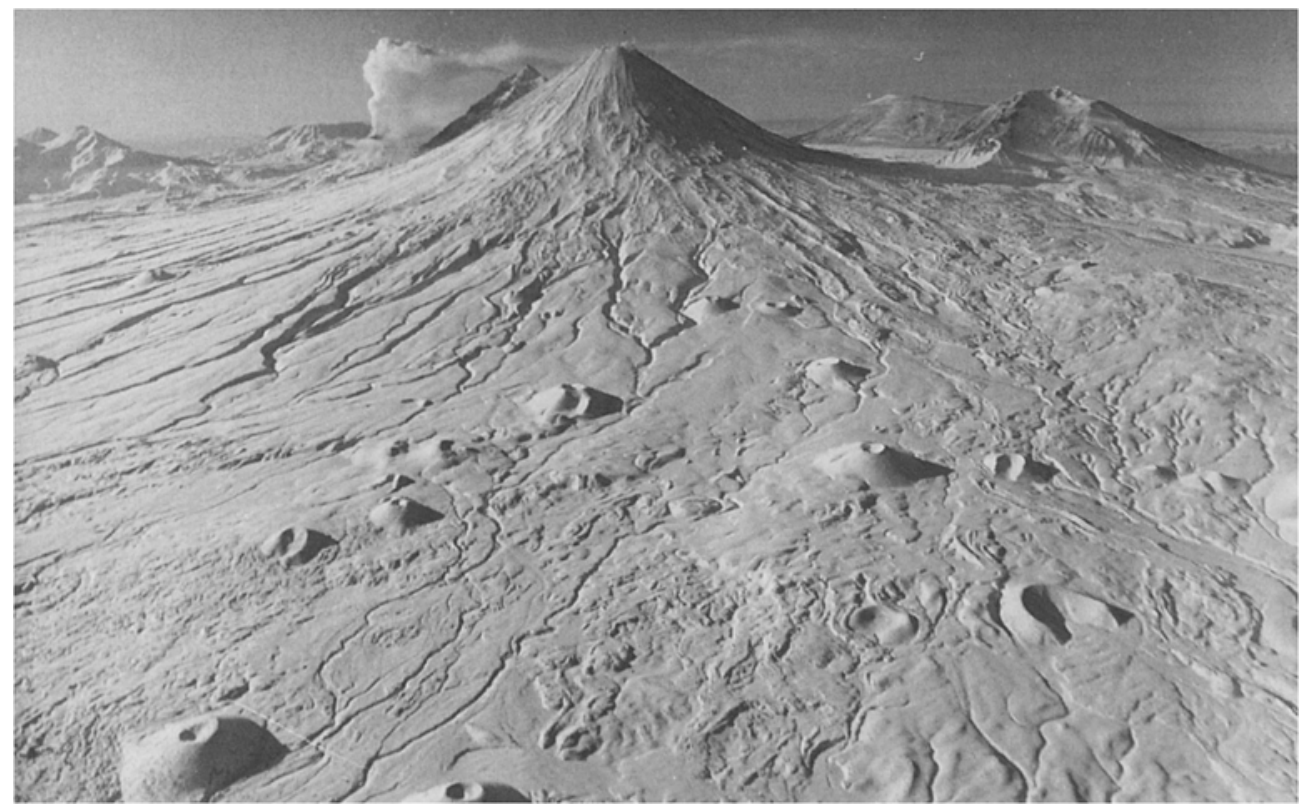

$1010 \pm 60 \quad$ (GIN-4936), $1090 \pm 100 \quad$ (GIN-4926) and $1110 \pm 40$ years (GIN-4933). Crater activity was renewed during a smaller eruption about 300 years ago and it finally gained its modern shape as a result of a violent explosive eruption in 1907.

The young cone of Iliinsky volcano began to form not earlier than 7600-7700 years ago, as it is located in Iliinsky caldera of roughly the same age. A large explosive crater on the east flank of the volcano may have formed later than 200 years ago. The date of $180 \pm 40$ years (GIN-4924) determined for soil underlying its deposits does not exclude the possibility that this was the eruption witnessed in 1901 (Novograblenov 1932).

Tephrochronological studies allow us to refine the earlier interpretation of Masurenkov (1980b) on two episodes of the Dikiy Greben volcano formation. Our studies suggest that this eruptive center located near the Kuril Lake caldera consists of a number of large extrusive domes emplaced during three short phases of activity separated by long repose periods. Its earliest eruptions (DG I stage) took place about 7600-7700 years BP, immediately after the Kuril Lake caldera collapse, as their fallout directly overlies the pyroclastic flows associated with this caldera. The second phase of activity (DG II) took place about 5000 years ago, which is supported by the position of its pyroclastic deposits at the stratigraphic level close to that of marker ash bed ZLT (Table 2). The largest part of the Dikiy Greben edifice, including profuse lava flows descending to the north and south from its summit (Mount Nepriyatnaya), formed about 1600 years ago (stage DG III), based on the dates on wood and soil buried by the pyroclastic surge deposits of this eruption (Table 4).

Estimates were made for the ages of three volcanoes in the northern Kuril Islands: Ebeko in Paramushir and Peak Nemo and Peak Krenitsyn in the Onekotan Island. Ebeko formed 2300-2400 years ago; radiocarbon dates for tephra from its earliest eruptions are $2270 \pm 60$ and $2410 \pm 60$ years. Peak Nemo started to form at the beginning of Holocene, about 9500 years ago. Tephra from its earliest eruptions is older than the overlapping buried soils dated at $9050 \pm 100$ and $9130 \pm 140$ years. Peak Krenitsyn is younger than 7500 years, which was determined from its position within the Tao-Rusyr caldera of roughly the same age.

\section{Monogenetic volcanoes}

A large cinder cone and related basaltic lava field (approximately $100 \mathrm{~km}^{2}$ ) on the east flank of the Sredinny Ridge in the upper reaches of the Right and Left Ozernaya rivers formed in early Holocene time. Lava flows overlying moraine deposits are covered with a soil-pyroclastic sequence of the entire Holocene period. The lowermost marker horizon in this sequence is the ash KHG dated at $6900-7000$ years, which rests on a $15 \mathrm{~cm}$ layer of eolian sandy loam.

We have established the general age progression for the largest cinder cones in the Tolbachik regional zone located immediately to the south of Tolbachik volcano (Fig. 1). The sequence of stages of volcanic unrest has been determined and a map of cinder cones and lava flows in the Tolbachik plateau has been compiled, specifying the age of volcanics in thousands of years (Braitseva et al. 1984; see revision of $\mathrm{SH}_{4}$ age in the present paper). Cones of stage I were built between 1800 and 10000 years ago. Cones of stage II are younger than 1800 years; among them are the largest cinder cones of the regional zone. Pelmen, Mount 1004 and Pre-Vysokaya were initiated between 1500 and 1800 years ago; Peschanye Gorki, Alaid, Kleshnya and Mount Vysokaya formed in a sequence immediately after each other within a short time interval 900-1000 
years ago. The youngest prehistoric cone is Zvezda cone, with an age of a few hundred years.

Estimates were made for the age of many monogenetic volcanoes of East Kamchatka (Figs 7 and 9). The small monogenetic Sopochka Duga volcano, located between Uzon and Krasheninnikov calderas, formed about 3200-3300 years ago; its tephra overlies the ash marker bed $\mathrm{AV}_{1}$ dated at 3500 years; over this tephra a date of $2990 \pm 40$ years (GIN-3022) has been obtained. Ages determined for some volcanic forms north of Krasheninnikov volcano are as follows (Ponomareva 1990): Krokur maar formed about 4300 years ago (a date obtained on soil underlying its deposits is $4320 \pm 110$ years (GIN-3020); Zametny cone was built about 3400 years ago (its deposits immediately underlie tephra from Sopochka Duga). A large maar (Dalnee Lake) formed in Uzon caldera in Holocene times. It is dated at about 7600-7700 years; its cinders lie between the tephra marker layers KRM (7700-7800 years) and KZ (75007600 years). Several large extrusive domes have been built at the Bolshoy Semiachik massif. The age of the Ivanov Dome determined from correlation with the dated marker ash KRM is roughly $8500-9000$ years. Korona and Ezh Domes were built about 5600 years ago; a date of $5620 \pm 50$ years (GIN-5281) has been obtained for peat underlying their tephra which lies under the $\mathrm{AV}_{5}$ marker layer dated at 5600 years (Fig. 7).

\section{Late Pleistocene volcanoes and calderas}

Isotopic-geochronological age determinations for Late Pleistocene calderas and volcanoes of the Kurile-Kamchatka region (Fig. 1A) are meager (Table 5, Fig. 11).

\section{Late Pleistocene calderas}

The large crater (caldera) within which the active Shiveluch volcano (young Shiveluch) is located seems to have formed about 30000 years ago as ashes from this caldera-forming eruption found in the bottom sediments in the Bering Sea and Litke Strait are dated at $30200 \pm 50$ years.

Uzon caldera formed 39000 years ago, as shown by the date obtained on soil at the base of welded tuffs which was exposed at the shore of the Kronotskoe Lake.

Krasheninnikov caldera is roughly the same age as the Uzon caldera; its pyroclastic flow deposits directly overlie the Uzon ignimbrites.

Karymsky Lake caldera may have formed within the time interval of 28000 to 48000 years ago according to data obtained by the fission track method (Masurenkov 1980a). Maly Semiachik caldera is roughly the same age (probably 25000-30000 years ago), as its tuffs overlie the pyroclastics from the Karymsky Lake caldera.

Khangar caldera formed around 38000-40000 years ago, as the age of intercalated tephra from its calderaforming eruptions in loess-like Upper Pleistocene deposits of the Central Kamchatka Depression ranges from $38000 \pm 1800$ to $40600 \pm 700$ years.

The date of $29900 \pm 900$ years was obtained for a large Late Pleistocene crater (caldera) at Mount Avachinsky somma, within which its young cone is located. This age was determined on organic matter extracted from the coastal marine deposits underlying the pyroclastics (debris avalanche and directed blast deposits) at the coast of the Avachinsky Bay in Petropavlovsk, which are linked to the formation of this crater (Melekestsev et al. 1991c).

Opala caldera formed 40000 years ago based on the dates obtained above and under the tephra from that eruption in peat bogs of coastal precipices in West Kamchatka (Table 5). Earler it was shown by Melekestsev et al. (1974a) that pyroclastic deposits in the Opala caldera are interbedded among glacial deposits of stage I of the Late Pleistocene glaciation and are overlapped by moraines of stage II. Dates obtained indicate that the Opala caldera can be correctly referred to the Late
Table 5 Ages of Late Pleistocene calderas in the KurileKamchatka region

\begin{tabular}{lcllc}
\hline Names of calderas & ${ }^{14}$ C ages (years) & $\begin{array}{l}\text { Laboratory } \\
\text { index }\end{array}$ & Comments & ${ }^{14}$ C ages (ka) \\
\hline Shiveluch & $30200 \pm 500$ & IVAN-148 & p & $\sim 30$ \\
Uzon & $39600 \pm 1000$ & GIN-1369 & bs & $\sim 39$ \\
Krasheninnikova & $<39600 \pm 1000$ & & & $-35-38(?)$ \\
Karymsky Lake & - & & & $28-48^{*}$ \\
Maly Semiachik & - & GIN-3404 & bs & $<28-48$ \\
Khangar & $38000 \pm 1800$ & GIN-3401 & bs & $38-40$ \\
Avachinsky crater & $29900 \pm 700$ & GIN-5563 & bs & $29-30$ \\
Opala & $39400 \pm 1400$ & GIN-3008 & p & $39-40$ \\
Gorely & -41000 & GIN-3009 & p & $33-34$ \\
Kuril Lake ('old') & $33600 \pm 700$ & GIN-5305 & bs & $40-41$ \\
Nemo III & $41500 \pm 900$ & GIN-6081 & bs & $24-25$ \\
Mendeleev & $24500 \pm 740$ & KSM-443 & bs & $39-40$ \\
Golovnin & $39300 \pm 600$ & GIN-124a & p & $38-39$ \\
\hline
\end{tabular}

* Dates determined by fission-track method. Other symbols as in Table 3. 

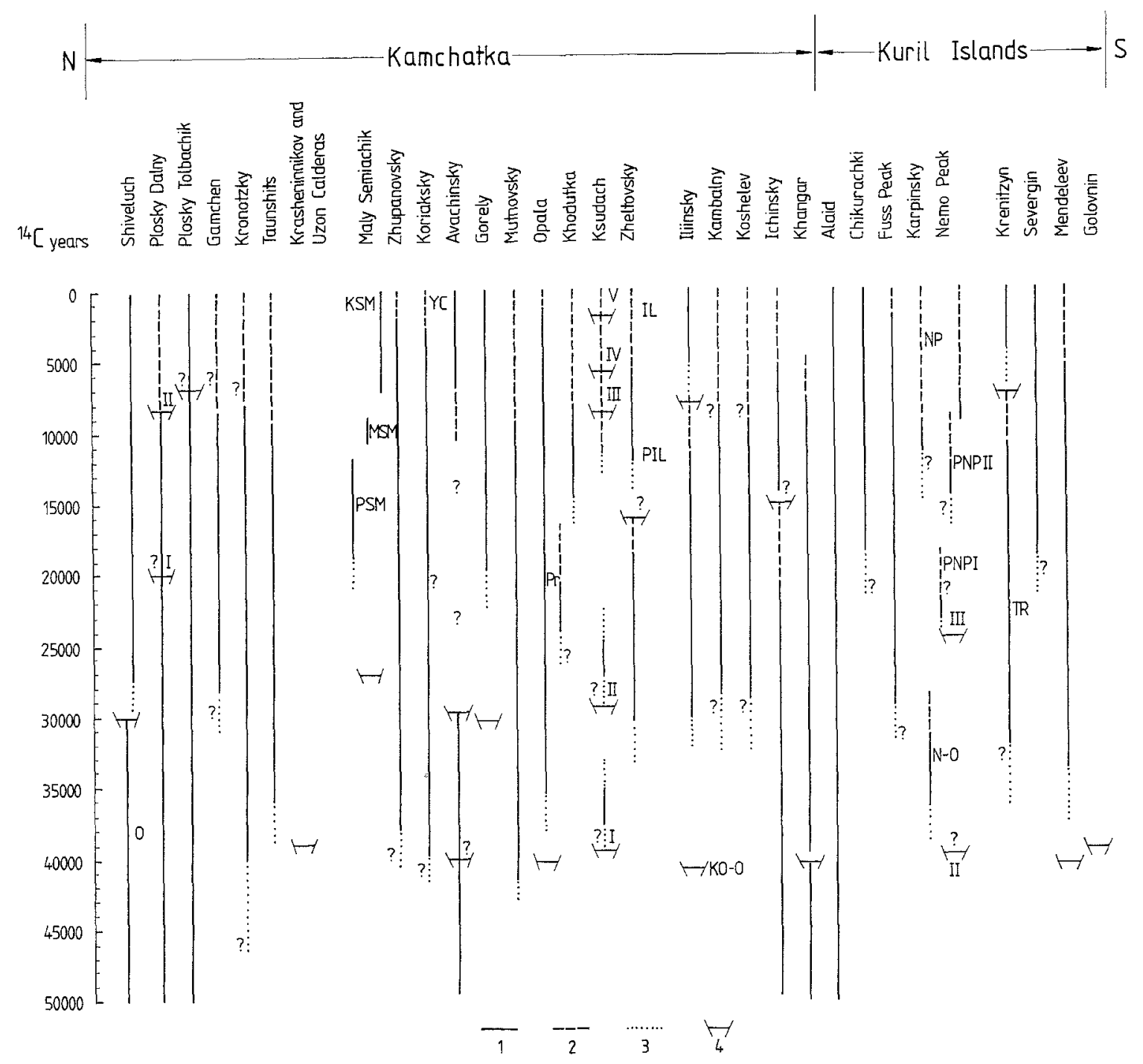

Fig. 11 Ages of active and potentially active volcanoes of the Late Pleistocene and dated Late Pleistocene calderas. 1, Period of intense volcanic activity; $\mathbf{2}$, period of waning volcanic activity, including fumarolic; 3 , periods of presumed early volcanic activity; and 4, calderas. Indices: $Y$, young Shiveluch; $O$, old Shiveluch; KSM, Kaino-Semiachik; MSM, Meso-Semiachik; PSM, PaleoSemiachik; YC, young cone of Avachinsky volcano; Pr, Priemysh; KO-O, old Kuril Lake caldera; PIL, Pre-Iliinsky; IL, Iliinsky; NP, Peak Nemo; PNPI, II, Pre-Peak Nemo I and II; N-O, old Nemo; and TR, Tao-Rusyr

Pleistocene Interstade. Gorely caldera is roughly the same age as the Opala caldera, as ignimbrites from its caldera-forming eruptions enter joints in the Opala pumice pyroclastic deposits. Dacite pumice tephra from one of the eruptions related to the formation of the Gorely caldera is underlain in Petropavlovsk by buried soils whose age is $33600 \pm 700$ years.

Radiocarbon dates for Ksudach calderas KSI and KSII are lacking. They are thought to be Late Pleistocene in age because of the good preservation of caldera morphology and correlation with stage II moraines of the Late Pleistocene glaciation. The calderas already existed during the climax of glaciation (20000-25000 years ago) and served as large ice basins (Melekestsev et al. 1974a).

The Late Pleistocene ('old') Kuril Lake caldera in south Kamchatka apparently formed about 4100042000 years ago. Ash from this caldera-forming eruption was identified and dated (Table 5) as far as the city of Magadan (about $1000 \mathrm{~km}$ from the vent; Melekestsev et al. 1991b).

Of three Nemo calderas on Onekotan Island, only the youngest (Nemo III) within which the presently active Nemo volcano is located was dated. The age of carbonized detritus on soils underlying the pyroclastics in the caldera is $24500 \pm 740$ years.

Mendeleev and Colovnin calderas on Kunashir Island are of a similar age. Mendeleev caldera formed about $39000-40000$ years ago, as shown by several accordant dates on peat underlying the pyroclastic deposits. Golovnin caldera formed about 38000 years ago, as shown by the date on peat underlying the pyroclastic deposits related to this caldera (Table 5). 
Fig. 12 Late Pleistocene Kronotsky volcano. View to north-east. Photo by N. A. Smelov

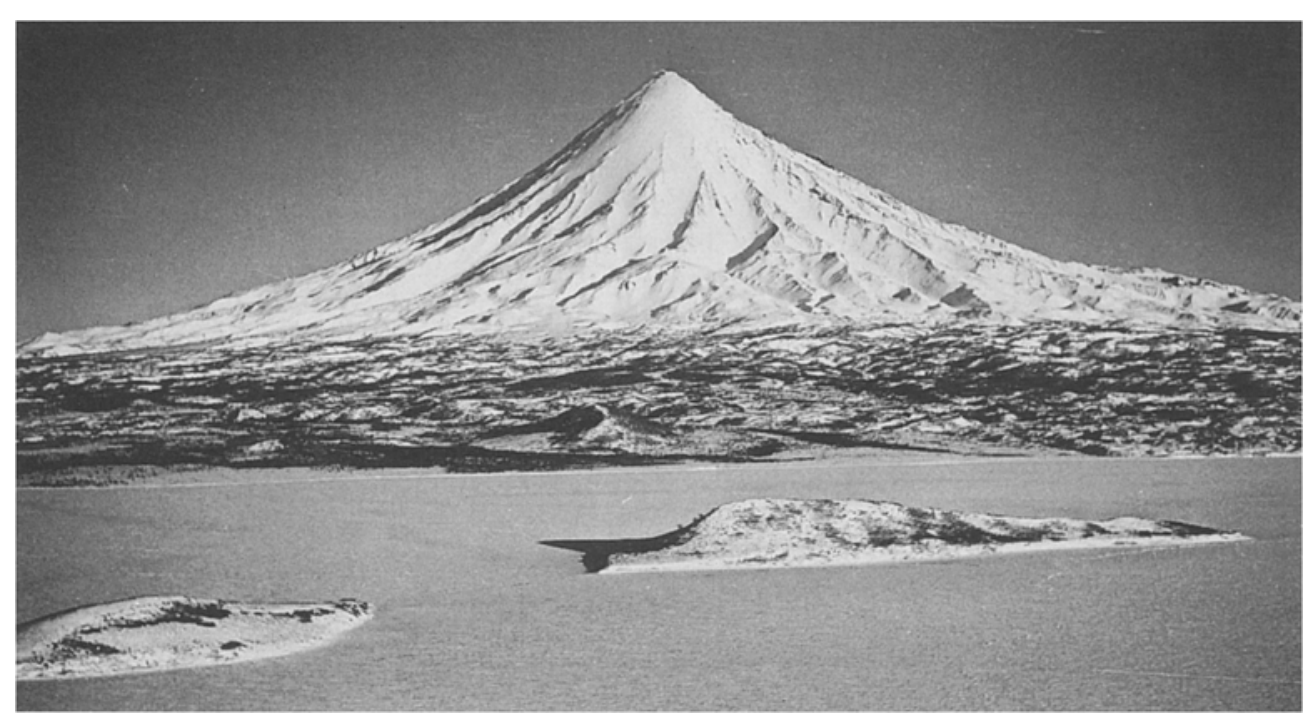

\section{Late Pleistocene volcanoes}

We have noted the difficulty in determining the radiocarbon age of Late Pleistocene volcanoes due to the poor preservation of their pyroclastic deposits and an organic matter deficiency in them. Numerous questionmarks in Fig. 11 show the limitations and ambiguity of our present state of study. Nevertheless, this figure shows the ages of recently active volcanoes which began to form in Late Pleistocene times, which we have compiled by combining geological-geomorphological evidence with the meager radiocarbon dates.

Maly Semiachik, Khangar, Opala (Fig. 8), Gorely and Peak Nemo are obviously younger than the dated Late Pleistocene calderas enclosing them. For some volcanoes located in the proximity of calderas, their ages were measured by correlation of their volcanics with the dated caldera pyroclastic deposits. Thus, for example, estimates obtained by using this correlation for the age of Taunshits volcano, whose lavas overlie the Uzon caldera ignimbrites, indicate an age $<39000$ years.

We assume that many recently active volcanoes that originated in Late Pleistocene times already existed as large volcanic edifices at the beginning stage II of the Late Pleistocene glaciation, as they were centers of glaciation during the main glacial pulse of stage II and supplied fresh material forming large moraines which surround the volcanic cones and cover large areas at their feet. At the same time they could not originate during stage I of the glaciation, as typical sculpturesque glacial forms such as cirques and troughs which formed at more ancient edifices are lacking on them (Melekestsev et al. 1971). We therefore assume that these volcanoes began to form between the two stages of the glaciation, roughly 40000-50000 years ago. These are Kronotsky (Fig. 12), Taunshits, Zhupanovsky, Koriaksky, Avachinsky, Kozelsky, Mutnovsky, Opala (Fig. 8), Khodutkinsky and some others (Fig. 10).

\section{Summary}

We have provided information on the age of most large Late Pleistocene and Holocene volcanic landforms, calderas and stratovolcanoes in Kamchatka. Fifteen 'Krakatoa-type' calderas formed here in the Late Pleistocene (Fig. 1A). The ages of 12 of them have been estimated. There is no data on three Late Pleistocene calderas: Ichinsky, Zheltovsky and Prizrak calderas. All calderas, except for Ichinsky and Khangar located in the Sredinny Ridge, were emplaced within the Eastern volcanic belt.

Six 'Krakatoa-type' calderas that emerged in Kamchatka during the Holocene are located within the Eastern volcanic belt and spatially associated with some of the Late Pleistocene calderas. The Holocene Kuril Lake and Iliinsky calderas are nested within the Late Pleistocene 'Old' Kuril Lake caldera. The Holocene Ksudach calderas (III, IV and V) are nested in Late Pleistocene calderas I and II. The Holocene Karymsky caldera is located nearby the Late Pleistocene Karymsky Lake caldera. No Holocene 'Krakatoa-type' calderas occur in the Kliuchevskoi volcano group, but two of three Holocene 'Hawaiian-type' calderas are located within it. Five of six Holocene 'Krakatoa-type' calderas in Kamchatka formed within the southern part of the Eastern volcanic belt and two more calderas formed in the Kuril Islands. Five large calderas are nested within the Ksudach massif, three of which formed in Holocene time. The Holocene calderas are much smaller in size and volume of ejecta than Late Pleistocene calderas.

Most Late Pleistocene calderas formed roughly 30000-40000 years ago (Table 5). All but one Holocene caldera in the Kuril-Kamchatka region formed in the first part of the Holocene between 9500 and 6000 years BP (Fig. 5).

Most of the Late Pleistocene stratovolcanoes in Kamchatka formed within the Eastern volcanic belt, 
except for two volcanoes that formed in the Sredinny Ridge. Stratovolcanoes have been formed throughout the entire Holocene period, but only within the Eastern volcanic belt. Monogenetic forms initiated in the Holocene both in the Eastern volcanic belt and in the Sredinny Ridge.

Although this chronicle contains some gaps, we can define periods of synchronous upsurge of volcanic activity in the Kuril-Kamchatka region in the Holocene. One of them is between 7800 and 7500 years ago when a powerful paroxysm of acid explosive volcanism took place. As a result, the calderas of Karymsky, Kuril Lake, Iliinsky and Tao-Rusyr were formed almost synchronously (Fig. 5), but in consecutive order from north to south. Simultaneously, large explosive eruptions of Kizimen (which produced the marker ash KZ), Taunshits and Shiveluch took place, and Dikiy Greben volcano began to form. After this paroxysm, the KainoSemiachik basaltic volcano started to form. Considering the estimated tephra volumes and the zonal atmospheric circulation, we suppose that the large explosive eruptions of this period are responsible for some of significant acidity peaks in Greenland ice cores (Zielinski et al. 1994) and may have contributed to climatic cooling.

One more period of synchronous upsurge of activity was 1800-1300 years ago when caldera $V$ at Ksudach and Baraniy Amfiteatr crater at Opala volcano formed. Several powerful explosive eruptions of Shiveluch volcano also took place (one of them produced the marker tephra $\mathrm{SH}_{3}$ ). In addition, several stratovolcanoes were initiated (Mid-North cone at Krasheninnikov, Savich cone at Kikhpinych and Shtyubel cone at Ksudach) and a huge extrusive dome (Mt Nepriyatnaya) was emplaced at Dikiy Greben volcano (Figs 5 and 7). This is also the time when magnesian basalts started to erupt in the Tolbachik regional zone (about 1600 years BP). Afterwards, during the last 1300 years, only one stratovolcano, Neo-Bezymianny, started to form.

According to our data, the duration of building large stratovolcanoes is estimated to be several thousand years. Thus small stratovolcanoes such as both cones of Kikhpinych, Shtyubel in the Ksudach massif and the Mid-North cone of Krasheninnikov formed their edifices in the main in only a few hundred years. It took a few thousand years for the following large stratovolcanoes to build their cones in the main: Young cone of Avachinsky volcano (3500 years), Bezymianny (3700 years) (Braitseva et al. 1991), North cone of Krasheninnikov (3100 years) (Ponomareva 1990), Karymsky (2800 years) (Braitseva and Melekestsev 1991) and Kaino-Semiachik (5200 years) (Braitseva et al. 1980). The cone of Kliuchevskoi grew for over 3000 years before its first flank eruptions started to occur roughly 3000 3500 years ago.

Volcanoes which started to form in the Holocene or at the very end of the Late Pleistocene have remained very active until the present time. A sustained supply of the volcanic material reduces the erosion-denudation effects to zero and is the reason for the good preservation of the initial volcanic edifice morphology (Figs 6 and 10). Most of the volcanoes that started to form in the Late Pleistocene exhibited waning activity in the Holocene. Minor supplies of volcanic material allowed denudation to promptly change the appearance of the volcano; it became dissected by deep gullies and by dry river valleys (Figs 8 and 12) and entered the stage of starting edifice destruction. Consequently, the preservation of the initial morphology of volcanic cones is mainly dependent on the intensity of volcanic activity, which is closely linked to the age of volcanoes (Melekestsev 1973).

Data obtained in Kamchatka and the Kuril Islands suggest that recently active volcanic cones of this area are geologically very young; their maximum age is roughly 50000 years; the most active volcanoes started to form only a few thousand years ago. These data are in good agreement with the results of radioisotopic age determinations for active volcanoes in other volcanic regions with different geotectonic environments (Thorarinsson 1967; Crandell and Mullineaux 1978; Aramaki et al. 1981; Ono et al. 1981; Tsuya et al. 1981; Chester et al. 1985; Easton 1987; Rose 1987).

Acknowledgements The research described in this paper was supported by grants from the Russian Fundamental Research Foundation and the International Science Foundation (grant RMG000). We are grateful to J. P. Lockwood, T. P. Miller and J. Fierstein for critically reviewing the manuscript.

\section{References}

Aramaki S, Fukuyama H, Kamo K, Kamada M (1981) Field Excursion Guide to Sakurajima, Kirishima and Aso Volcanoes. Part I. Tokyo: 1-17

Braitseva OA, Melekestsev IV (1991) Eruptive history of Karymsky volcano, Kamchatka, USSR, based on tephra stratigraphy and ${ }^{14} \mathrm{C}$ dating. Bull Volcanol 53:195-206

Braitseva OA, Melekestsev IV, Erlich EN (1974) Most recent volcanic activity. In: Luchitsky IV (ed) Kamchatka, Kurile and Commander Islands. Nauka, Moscow, pp 369-394 [in Russian]

Braitseva OA, Egorova IA, Sulerzhitsky LD, Nesmachny IA (1980) Maly Semiachik volcano. In: Masurenkov YuP (ed) A Volcanic Center: Structure, Dynamics and Substance of the Karymsky Center. Nauka, Moscow, pp 199-235 [in Russian]

Braitseva OA, Melekestsev IV, Flerov GB, Ponomareva VV, Sulerzhitsky LD, Litasova SN (1984) Holocene volcanism of the Tolbachik regional zone of cinder cones. In: Fedotov SA (ed) Great Tolbachik Fissure Eruption, Kamchatka, 1975-1976. Nauka, Moscow, pp 177-209 [in Russian]

Braitseva OA, Litasova SN, Ponomarenko AK (1987) Application of tephrochronological dating to determine the age of a key archaeological site in Eastern Kamchatka. Volcanol Seismol 5:507-514

Braitseva OA, Florenskii IV, Ponomareva VV, Litasova SN (1989a) The history of the activity of Kikhpinych volcano in the Holocene. Volcanol Seismol 7:895-872

Braitseva OA, Kirianov VYu, Sulerzhitsky LD (1989b) Marker intercalations of Holocene tephra in the Eastern volcanic zone of Kamchatka. Volcanol Seismol 7:785-814

Braitseva OA, Melekestsev IV, Bogoyavlenskaya GE, Maksimov AP (1991) Bezymianny volcano: the history of formation and activity dynamics. Volcanol Seismol 12:165-194 
Braitseva OA, Litasova SN, Sulerzhitsky LD (1992a) Validity of radiocarbon dating in regions of active volcanism in Kamchatka. Quaternary Int 13/14:143-146

Braitseva OA, Melekestsev IV, Ponomareva VV, Kirianov VYu, Litasova SN, Sulerzhitsky LD (1992b) Tephra of the largest pre-historic eruptions of Kamchatkan volcanoes in Holocene. Quat Int 13/14:177-180

Braitseva OA Sulerzhitsky LD, Litasova SN, Melekestsev IV, Ponomareva VV (1993) Radiocarbon dating and tephrochronology in Kamchatka. Radiocarbon 35:463-476

Chester DK, Duncan AM, Guest IE, Kilburn CKI (1985) Mount Etna. The Anatomy of a Volcano. Cambridge Univ Press, Cambridge, $404 \mathrm{pp}$

Crandell DR, Mullineaux DR (1978) Geology of Mount St. Helens volcano Washington. Geol Surv Bull 1383-C:1-26

Easton RM (1987) Stratigraphy of Kilauea volcano. In: Volcanism in Hawaii. Geol Surv Prof Pap 1350:243-260

Gill J (1981) Orogenic Andesites and Plate Tectonics. Springer, Berlin, 390 pp

Gushchenko II (1965) Ashes from North Kamchatka and Conditions of their Formation. Nauka Moscow 144 pp [in Russian]

Kraevaya TS (1967) New data on the age of the Kuril Lake young pumice deposits. Voprosy Geografii Kamchatki, Petropavlovsk-Kamchatsky 5:128-129 [in Russian]

Masurenkov YuP (ed) (1980a) A Volcanic Center: Structure, Dynamics and Substance of the Karymsky Center. Nauka, Moscow, 300 pp [in Russian]

Masurenkov YuP (ed) (1980b) Long existing center of endogenic activity in South Kamchatka. Nauka, Moscow, 172 pp [in Russian]

Melekestsev IV (1973) Types and age for active volcanoes in the Kurile-Kamchatka region. Bull Volcanol Stantsii 48:17-23 [in Russian]

Melekestsev IV, Braitseva OA (1988) Giant collapses on volcanoes. Volcanol Seismol 6:495--508

Melekestsev IV, Sulerzhitsky LD (1990) Ksudach volcano (Kamchatka) over the last ten thousand years. Volcanol Seismol 9:537-556

Melekestsev IV, Braitseva OA, Kraevaya TS (1970) Application of the complex techniques to determine the age of Quaternary volcanic formations (in the case of Kamchatka). Izv AN SSSR Ser Geol 10:149-153 [in Russian]

Melekestsev IV, Braitseva OA, Sulerzhitsky LD, Kozhemyaka NN, Ogorodov NV, Egorova IA, Lupikina EG (1971) The age of volcanoes of the Kurile-Kamchatka volcanic region. In: Volcanism and the Deep Interior of the Earth. Nauka, Moscow, pp 68-75 [in Russian]

Melekestsev IV, Braitseva OA, Erlich EN, Kozhemyaka NN (1974a) Volcanic mountains and plains. In: Luchitsky IV (ed) Kamchatka, Kurile and Commander Islands. Nauka, Moscow, pp 162-234 [in Russian]

Melekestsev IV, Egorova IL, Lupikina EG (1974b) Inner ridge of the Kurile islands arc. In: Luchitsky IV (ed) Kamchatka, Kurile and Commander Islands. Nauka, Moscow, pp 265-327 [in Russian]

Melekestsev IV, Braitseva OA, Ponomareva VV, Sulerzhitsky LD (1990) Ages and dynamics of the active volcanoes of the Kurile-Kamchatka tegion. Int Geol Rev 32:436-448
Melekestsev IV, Felitsyn SB, Kirianov VYu (1991a) Opala volcano eruption. A.D., 500 - the largest explosive eruption on Kamchatka in our era. Volcanol Seismol 13:21-36

Melekestsev IV, Glushkova OYu, Kirianov VYu, Lozhkin AV, Sulerzhitsky LD (1991b) The origin and age of the Magadan volcanic ashes. Dokl AN SSSR 317:1187-1192

Melekestsev IV, Litasova SN, Sulerzhitsky LD (1991c) On the age and scale of the directed-blast catastrophic eruption of the Avachinsky volcano (Kamchatka) in the Late Pleistocene. Volcanol Seismol 13:135-146

Melekestsev IV, Ponomareva VV, Volynets ON (1995) Kizimen volcano, Kamchatka - a future Mount St. Helens? J Volcanol Geotherm Res 65:205-226

Novograblenov PT (1932) The catalogue of volcanoes of Kamchatka. Isv Gos Geogr Sci XIY-1:88-99 [in Russian]

Ono K, Soya T, Mimura K (1981) Volcanoes of Japan (second edition) 1:2000000 Map Series, Geol Surv Japan, Tokyo

Piyp Bl (1956) Kliuchevskoi volcano and its eruptions during 1944-1945 and in the past. Proc Lab Volcanol AN SSSR, Moscow, 310 pp [in Russian]

Ponomareva VV (1990) The history of Krasheninnikov volcano and the dynamics of its activity. Volcanol Seismol 9:714-741

Rose WI (1987) Santa Maria Guatemala: bimodal soda-rich calcalkalic stratovolcano. J Volcanol Geotherm Res 33:109-129

Rubin M, Lockwood JP, Friedman I (1987) Effects of volcanic emanations on carbon-isotope content of modern plants near Kilauea volcano. In: Volcanism in Hawaii. US Geol Survey Prof Pap 1350:209-211

Selyangin OB (1990) Geological structure and evolution of the calderas of Ksudach volcano. Volcanol Seismol 9:690-713

Selyangin OB, Braitseva OA, Egorova IA, Sulerzhitsky LD, Nesmachny IA (1979) Geological and tephrochronological studies of recent volcanoes. In: Problems of Deep Magmatism. Nauka, Moscow, pp 31-49 [in Russian]

Sheimovich VS, Patoka MG (1979) Opala and other Holocene centers of explosive eruptions in southern Kamchatka. Volcanol Seismol 5:92-95 [in Russian]

Sibrava V, Bowen DQ, Richmond GM (eds) (1986) Quaternary glaciations in the Northern Hemisphere. Quat Sci Rev 5:511

Sulerzhitsky LD (1970) Radiocarbon dating of volcanoes. Bull Volcanol 35:85-94

Thorarinsson S (1967) Hekla and Kafla. The share of acid and intermediate lava and tephra in the volcanic products through the geological history in Iceland. In: Iceland and Mid Ocean Ridges. Soc Sci Iceland 2:51-70

Tsuya H, Machida E, Shimozuru S (1981) Field Excursion Guide to Fuji, Asama Kusatsi-Shirane and Nantai Volcanoes. Part I. Tokyo, $22 \mathrm{pp}$

Vlodavets VI (ed) (1957) Catalogue of the active volcanoes of the USSR. In: Bull Volcanol Stancii 25:180 pp [in Russian]

Zielinski GA, Mayewski PA, Meeker LD, Whitlow S, Twickler MS, Morrison M, Meese DA, Gow AJ, Alley RB (1994) Record of volcanism since 7000 B.C. from the GISP2 Greenland ice core and implications for the volcano-climate system. Science 264:948-952 